\title{
GABA receptors: pharmacological potential and pitfalls
}

Maja Jazvinšćak Jembrek ${ }^{1,2}$, Josipa Vlainić ${ }^{1 *}$

${ }^{1}$ Laboratory for Molecular Neuropharmacology, Division of Molecular Medicine, Ruđer Bošković Institute, Zagreb, Croatia

${ }^{2}$ Croatian Catholic University, Department of Psychology, Zagreb, Croatia

*Corresponding author

Josipa Vlainić

Laboratory for Molecular Neuropharmacology

Division of Molecular Medicine

Ruđer Bošković Institute

10000 Zagreb, Croatia

Email: josipa.vlainic@irb.hr 


\begin{abstract}
Gamma-amino butyric acid (GABA), the major inhibitory neurotransmitter in the mammalian central nervous system, plays a key role in the regulation of neuronal transmission throughout the brain, affecting numerous physiological and psychological processes. Changes in GABA levels provoke disbalance between excitatory and inhibitory signals, and are involved in the development of numerous neuropsychiatric disorders. GABA exerts its effects via ionotropic $\left(\mathrm{GABA}_{\mathrm{A}}\right)$ and metabotropic $\left(\mathrm{GABA}_{\mathrm{B}}\right)$ receptors. Both types of receptors are targeted by many clinically important drugs that affect GABAergic function and are widely used in the treatment of anxiety disorder, epilepsy, insomnia, spasticity, aggressive behaviour, and other pathophysiological conditions and diseases. Of particular importance are drugs that modulate $\mathrm{GABA}_{\mathrm{A}}$ receptor complex, such as benzodiazepines, barbiturates, neuroactive steroids, intravenous and inhalational anesthetics, and ethanol. Molecular interactions and subsequent pharmacological effects induced by drugs acting at $\mathrm{GABA}_{\mathrm{A}}$ receptors are extremely complex due to structural heterogeneity of $\mathrm{GABA}_{\mathrm{A}}$ receptors and existence of numerous allosterically interconnected binding sites and various chemically distinct ligands that are able to bound to them. There is a growing interest in the development and application of subtype-selective drugs that will achieve specific therapeutic benefits without undesirable side effects. The aim of this review is to briefly summarize the key pharmacological properties of GABA receptors, and to present selected novel findings with the potential to open new perspectives in the development of more effective therapeutic strategies.
\end{abstract}

Keywords: GABA, GABA receptor pharmacology, benzodiazepines, neurosteroids 


\section{Introduction to GABA receptor diversity and pharmacological complexity}

As the principal mediator of inhibitory synaptic transmission in the mammalian brain, GABA exerts its effects and shapes behaviour via two different types of GABA receptors. While fast ionotropic $\mathrm{GABA}_{\mathrm{A}}$ receptors belong to the family of ligand gated ion channels, metabotropic $\mathrm{GABA}_{\mathrm{B}}$ receptors are receptors with seven transmembrane domains coupled to G-proteins. Activation of GABA receptors by GABA induces membrane hyperpolarization, reduces the frequency of the generation of action potentials, and results in inhibition. Mainly local-circuit interneurons that constitute $15-20 \%$ of all cortical neurons predominantly use GABA as the neurotransmitter [1-3].

Most of its effects $\mathrm{GABA}$ exerts via $\mathrm{GABA}_{\mathrm{A}}$ receptors. $\mathrm{GABA}_{\mathrm{A}}$ receptors may be embedded in postsynaptic membrane where they mediate transient and fast synaptic inhibition that occurs in milliseconds, or may be located at the extrasynaptic places where respond to ambient concentrations of GABA and mediate long-term inhibition. In fast synaptic inhibition, GABA released from the presynaptic membrane terminals rapidly diffuses across the synaptic cleft and binds to binding sites at postsynaptic $\mathrm{GABA}_{\mathrm{A}}$ receptors. Following binding, these receptors undergo a rapid conformational change that opens integral chloride channel and permit the flow of chloride ions down their chemical gradient, across the postsynaptic membrane. This ensures propagation of neurotransmission and represents basis of neural communication $[4,5]$.

In contrast to GABA that directly activates and opens ion channels, some drugs, such as competitive antagonist bicuculline, selectively block $\mathrm{GABA}_{\mathrm{A}}$ receptors and prevent inhibitory action of GABA. Muscimol, the principal psychoactive constituent of the mushroom Amanita muscaria, also acts as a potent, selective agonist of $\mathrm{GABA}_{\mathrm{A}}$ receptors. $\mathrm{A}$ variety of clinically important drugs, including anticonvulsants, anxiolytics, general anesthetics, barbiturates, ethanol and neuroactive steroids, as well as drugs important as research tool such as convulsive picrotoxin, allosterically modulate GABA-induced activation of $\mathrm{GABA}_{\mathrm{A}}$ receptors by acting on distinct binding sites on the receptor and modulate GABA action $[5,6]$. These drug interactions, together with structural diversity of $\mathrm{GABA}_{\mathrm{A}}$ receptors, shape the complex nature of $\mathrm{GABA}_{\mathrm{A}}$ receptor pharmacology, although simultaneously offer a great opportunity for the design of novel and more selective compounds for improved therapeutic applications [7]. Unfortunately, severe problems are related to the long-term use of drugs acting at $\mathrm{GABA}_{\mathrm{A}}$ receptors, including loss of efficacy, and development of tolerance 
and dependence that largely limit the time window of their desirable therapeutic benefits $[4,8$ $11]$.

GABA also achieves inhibitory effects by acting at G-protein-coupled metabotropic $\mathrm{GABA}_{\mathrm{B}}$ receptors. The slow, longer-lasting inhibition of $\mathrm{GABA}_{\mathrm{B}}$ receptors is mediated by indirect gating of either potassium or calcium channels via second messengers. Characteristic agonists of $\mathrm{GABA}_{\mathrm{B}}$ are the GABA analog baclofen and 3-aminopropylphosponous acid (3APPA; CGP27492), while saclofen, phaclofen and 2-hydroxysaclofen act as antagonists of $\mathrm{GABA}_{\mathrm{B}}$ receptors [12].

Old nomenclature also included $\mathrm{GABA}_{\mathrm{C}}$ receptors that are expressed predominantly in retina. However, International Union of Basic and Clinical Pharmacology has recommended that $\mathrm{GABA}_{\mathrm{C}}$ receptors should be assumed as one of the many isoforms of $\mathrm{GABA}_{\mathrm{A}}$ receptors [5].

\section{$\mathrm{GABA}_{\mathrm{A}}$ receptors and their subunits}

Ubiquitously expressed $\mathrm{GABA}_{\mathrm{A}}$ receptors are the major receptors of inhibitory neurotransmission across the central nervous system (CNS) that play a major role in virtually all brain physiological functions. $\mathrm{GABA}_{\mathrm{A}}$ receptors are heteropentameric ligand-gated proteins that form a channel specific for chloride ions as an integral part. $\mathrm{GABA}_{\mathrm{A}}$ receptors are members of the Cys-loop ligand-gated ion channel superfamily due to the presence of a disulphide-bridged loop in the extracellular domain. They share structural and functional homology with other members of the family. In addition to $\mathrm{GABA}_{\mathrm{A}}$ receptors, the main pentameric receptors within the Cys-loop superfamily are nicotinic acetylcholine (nACh), 5hydroxytryptamine type $3\left(5 \mathrm{HT}_{3}\right)$ and glycine receptors $[13,14]$.

$\mathrm{GABA}_{\mathrm{A}}$ receptors are assembled from an impressive repertoire of different homologous subunits that are encoded from the pool of 19 different genes. Six $\alpha\left(\alpha_{1-6}\right)$, three $\beta$ $\left(\beta_{1-3}\right)$, three $\gamma\left(\gamma_{1-3}\right), \delta, \varepsilon, \theta, \pi$ and three $\rho\left(\rho_{1-3}\right)$ subunits have been identified by molecular cloning techniques $[6,14-16]$. In some cells expression of more than eight different isoforms has been demonstrated [5]. Throughout the CNS some subunits are broadly expressed, while others exhibit more restricted expression profile [17,18]. For example, the most abundant $\alpha 1$ subunit is expressed almost ubiquitously in the brain, $\alpha 5$ is highly expressed in the hippocampus, $\alpha 6$ subunit is expressed only in granule cells of the cerebellum, while $\rho$ subunits, the major molecular components of the formerly called $\mathrm{GABA}_{\mathrm{C}}$ receptors, are expressed mainly in the retina [19-22]. Expression of $\beta 2$ subunit strongly correlates with that 
of $\alpha 1$, while expression pattern of $\beta 3$ subunit resembles to that of $\alpha 2$. Isoform $\gamma 2$ is the most widely distributed isoform of $\gamma$ subunit [17].

$\mathrm{GABA}_{\mathrm{A}}$ receptor subtypes composed of different subunits represent distinct receptor populations that exhibit unique functional and pharmacological properties, and are differentially regulated at the transcriptional, post-transcriptional and translational levels [23]. $\mathrm{GABA}_{\mathrm{A}}$ receptor subtypes are expressed in a specific spatio-temporal pattern in the developing and adult CNS. Some combinations of subunits, such as $\alpha 1 \beta 2 \gamma 2$, the most prevalent adult isoform, are broadly distributed in different brain areas, while the expression of some other subtypes of $\mathrm{GABA}_{\mathrm{A}}$ receptors is restricted to certain regions [24].

Mature subunits share a common topological organization, and have approximately 450 amino acid residues in length. Subunits consist of a large extracellular N-terminal domain that contains already mentioned Cys loop, followed by four transmembrane domains (TM1TM4), and a short extracellular C-terminal domain. TM2 domains of all five subunits line the lumen of ion channel. There is a large phosphorytable intracellular loop between TM3 and TM4 domains of each subunit that participates in protein-protein interactions and plays an important role in the regulation of $\mathrm{GABA}_{\mathrm{A}}$ receptor function. Some of the intracellular proteins that interact with $\mathrm{GABA}_{\mathrm{A}}$ receptors are $\mathrm{GABA}_{\mathrm{A}}$ receptor associated protein (GABARAP), Golgi-specific DHHC zinc finger protein (GODZ) phospholipase C-related, catalytically inactive proteins PRIP-1 and PRIP-2, Plic-1, radixin, GABA $\mathrm{A}_{\mathrm{A}}$ receptors interacting factor-1 (GRIF-1), and brefeldin A-inhibited GDP/GTP exchange factor 2 (BIG2). These proteins interact with particular subunits at $\mathrm{GABA}_{\mathrm{A}}$ receptor complex and modulate broad spectrum of $\mathrm{GABA}_{\mathrm{A}}$ receptors activities, such as trafficking enhancement, surface stabilization, receptor internalization, anchoring of receptors in the cytoskeleton, and regulation of modification of $\mathrm{GABA}_{\mathrm{A}}$ receptors [5,25].

Chromosomal mapping techniques revealed that the majority of genes coding for the subunits of $\mathrm{GABA}_{\mathrm{A}}$ receptors are localized into four clusters on chromosomes 4, 5, 15 and $\mathrm{X}$ in the human genome, and within these clusters genes have conserved transcriptional orientation [26]. Additional diversity of receptor structure is accomplished by alternative splicing of some of the subunit mRNAs and by RNA editing that might affect kinetics, subunit assembly and cell-surface expression of $\mathrm{GABA}_{\mathrm{A}}$ receptors [27]. For example, the $\gamma_{2}$ subunit appears in three alternatively spliced variants termed $\gamma 2 \mathrm{~L}, \gamma 2 \mathrm{~S}$ and $\gamma 2 \mathrm{XL}$ [28], although physiological and pharmacological relevance of this diversity is still not completely resolved. Nova, a neuron-specific RNA binding protein, regulates alternative splicing of $\gamma 2$ subunit by acting on an intronic splicing enhancer which lies far downstream of the regulated 
exon, and general dysregulation of Nova's splicing enhancer function may underlie the neurologic defects seen in patients with Nova's absence [29].

Only a limited number of mutations have been found in $\mathrm{GABA}_{\mathrm{A}}$ receptor subunit genes that are specific for different diseases. For example, point mutations in the $\alpha 1$ and $\gamma 2$ subunits are found in patients with genetic epilepsies, while single nucleotide polymorphisms (SNPs) in the gene encoding the $\alpha 2$ subunit are involved in alcohol dependence and illicit drug dependence. The gene encoding the $\beta 1$ subunit also has been linked to alcohol dependence and to bipolar disorder. The genes encoding the $\alpha 1, \alpha 6, \beta 2$ and $\pi$ subunits have been linked to schizophrenia [4].

\section{Subunit composition determines pharmacological effects}

It is still not resolved which subunits assemble together to form different isoforms of $\mathrm{GABA}_{\mathrm{A}}$ receptors that really exist in nature [14]. Numerous expression studies using recombinant receptors indicated that receptors composed of $\alpha, \beta$, and $\gamma$ subunits form $\mathrm{GABA}_{\mathrm{A}}$ receptors with a pharmacological profile that mimic properties of the majority of native receptors. Despite the fact that the immense number of different pentameric combinations can be assembled from the pool of native protein subunits, it seems that the prevalent form of native $\mathrm{GABA}_{\mathrm{A}}$ receptors is the combination of two $\alpha$, two $\beta$ and a single $\gamma, \delta$ or $\varepsilon$ subunit [30,31]. As mentioned before, isoform $\alpha 1 \beta 2 \gamma 2$ is considered as the most prevalent subtype of adult $\mathrm{GABA}_{\mathrm{A}}$ receptors, with $\gamma 2 \beta 2 \alpha 1 \beta 2 \alpha 1$ counter-clockwise arrangement surrounding central ion pore when viewed from the synaptic cleft [32]. It is estimated that approximately $60 \%$ of all $\mathrm{GABA}_{\mathrm{A}}$ receptors have the subunit composition $\alpha 1 \beta 2 \gamma 2$, approximately $15-20 \%$ have the $\alpha 2 \beta 3 \gamma 2$ combination, approximately $10-15 \%$ have the $\alpha 3 \beta \mathrm{n} \gamma 2$ combination, approximately $5 \%$ have the $\alpha 4 \beta \mathrm{n} \gamma$ or $\alpha 4 \beta \mathrm{n} \delta$ combination, less than $5 \%$ have the $\alpha 5 \beta 2 \gamma 2$ combination and, likewise, less than $5 \%$ have the $\alpha 6 \beta 2 / 3 \gamma 2$ combination [4]. Furthermore, it is possible for $\mathrm{GABA}_{\mathrm{A}}$ receptors to contain two different $\alpha$ subunits. Thus, $\alpha 1 \alpha 6 \beta \mathrm{x} \gamma 2$ and $\alpha 1 \alpha 6 \beta \times \delta$ receptors have been found in the cerebellum [33].

Composition and arrangement of $\mathrm{GABA}_{\mathrm{A}}$ receptors subunits shapes the synaptic response to GABA, as well as electrophysiological, functional and pharmacological properties of $\mathrm{GABA}_{\mathrm{A}}$ receptors, including potency and efficacy of different drugs to exert their effects [6,34,35]. For example, Zezula et al. [36] systematically investigated properties of recombinant $\mathrm{GABA}_{\mathrm{A}}$ receptors formed after transfection of human embryonic kidney (HEK) 293 cells with $\alpha 1-, \beta 3-$, or $\gamma 2$-subunits, or with various combinations of these subunits. From 
all possible subunit combinations, high affinity binding sites for GABA were formed in cells transfected with $\alpha 1 \beta 3$ - or $\alpha 1 \beta 3 \gamma 2$-subunits only. Binding of benzodiazepines were induced in cells after transfection with $\alpha 1 \gamma 2$ - or $\alpha 1 \beta 3 \gamma 2$ subunits, whereas binding sites for convulsant $\left[{ }^{35} \mathrm{~S}\right] \mathrm{t}-$ butylbicyclophosphorothionate (TBPS) were found in cells transfected with $\beta 3-, \beta 3 \gamma 2-$, $\alpha 1 \beta 3-$, or $\alpha 1 \beta 3 \gamma 2$-subunits. Binding of $\left[{ }^{35} \mathrm{~S}\right] \mathrm{TBPS}$ was inhibited by pentobarbital (barbiturate), alphaxalone (anesthetic neuroactive steroid) and propofol (anesthetic) with a potency which differed in cells transfected with $\beta 3-, \beta 3 \gamma 2-, \alpha 1 \beta 3-$, or $\alpha 1 \beta 3 \gamma 2$-subunits, demonstrating that receptors with different subunit composition exhibit distinct pharmacological properties.

\section{Tonic and phasic inhibition by $\mathrm{GABA}_{\mathrm{A}}$ receptors}

Some subunits, such as $\delta$ subunits, are placed only at extrasynaptic places where $\mathrm{GABA}_{\mathrm{A}}$ receptors are activated by low ambient GABA concentrations present in the extracellular fluid, and mediate a so-called tonic inhibition that is relatively non-desensitizing. Isoforms containing $\gamma$ subunit are expressed predominantly at synapses and mediate rapidly desensitizing phasic GABAergic neurotransmission. Synaptic $\mathrm{GABA}_{\mathrm{A}}$ receptors are activated transiently after the release of GABA from presynaptic vesicles, while extrasynaptic $\mathrm{GABA}_{\mathrm{A}}$ receptors are in general activated continuously, controlling neuronal excitability and the strength of synaptic transmission [37-41].

Tonic and phasic conductances underlie different physiological and behavioural processes [4]. Receptors containing $\delta$ subunit regulate numerous behavioural functions, including memory, nociception and anxiety, and may modulate neurogenesis. Taking into account that they are highly responsive to sedative-hypnotic and sleep-promoting drugs, general anesthetics, alcohol and neuroactive steroids, they are considered as potential therapeutic targets for the treatment of memory impairment, insomnia, mood disorders, pain, and post-stroke recovery [39,41-44].

Furthermore, extrasynaptic $\mathrm{GABA}_{\mathrm{A}}$ receptors with $\delta$ subunit exhibit a pronounced variability in expression levels under different physiological and pathophysiological conditions that might reshape behaviour and change neuronal susceptibility to different drugs [41]. Modulation of tonic inhibition might be of clinical relevance as extrasynaptic $\mathrm{GABA}_{\mathrm{A}}$ receptors may diminish seizure susceptibility and states of anxiety during the estrous cycle. In particular, in late diestrus in mice (high-progesteron phase), increased expression of $\delta$ containing receptors increases tonic inhibition, suggesting that consequent reduction of 
neuronal excitability might be beneficial in women with catamenial epilepsy and premenstrual dysphoric disorder [45]. The large increase in progesterone-derived neurosteroids during pregnancy, and their sharp decline at parturition, may also have considerable effects on $\mathrm{GABA}_{\mathrm{A}}$ receptors during pregnancy and postpartum. Both tonic and phasic inhibition decrease in pregnant mice due to down-regulation of $\delta$ and $\gamma 2$ subunits, and are rebound immediately after delivery. Mice which do not exhibit $\delta$-subunit regulation throughout pregnancy show depression-like and abnormal maternal behaviours [46]. On the other hand, expression of $\mathrm{GABA}_{\mathrm{A}}$ receptors containing $\delta$ subunit is diminished in depression and schizophrenia $[47,48]$.

\section{Endogenous ligands of $\mathrm{GABAA}_{\mathrm{A}}$ receptors}

In addition to GABA, neurosteroids are the most important endogenous ligands of $\mathrm{GABA}_{\mathrm{A}}$ receptors. Certain neurosteroids potently and specifically enhance function of $\mathrm{GABA}_{\mathrm{A}}$ receptors, and consequently exert anxiolytic, analgesic, anticonvulsant, sedative, hypnotic and anesthetic properties, and contribute to behavioural effects of psychoactive substances [49]. In the CNS, steroids can be synthesized de novo from cholesterol, during stress, pregnancy and after ethanol consumption, and these steroids are called neurosteroids, or can be converted from steroid precursors from periphery [50-52]. De novo synthesized neuroactive steroids locally modify neuronal activity in a paracrine manner, and can influence mood and behaviour in various physiological and pathophysiological conditions. GABAmodulatory actions of the pregnane steroids are highly selective, with their actions being brain region- and neuron-dependent. Furthermore, the sensitivity of $\mathrm{GABA}_{\mathrm{A}}$ receptors to neurosteroids is not static but can dynamically change. The molecular mechanisms determining this neuronal specificity include different $\mathrm{GABA}_{\mathrm{A}}$ receptor isoforms, protein phosphorylation and local steroid metabolism and synthesis [53,54].

Relatively recently, it has been discovered that endocannabinoid 2-arachidonoyl glycerol (2-AG) potentiates $\mathrm{GABA}_{\mathrm{A}}$ receptors at low concentrations of GABA, specifically in receptors containing $\beta 2$ subunit [55]. 2-AG allosterically potentiates $G_{A B A_{A}}$ receptors via a binding site located in transmembrane segment TM4 of the $\beta 2$ subunit $\mathrm{GABA}_{\mathrm{A}}$ receptors [56]. The discovery of a direct action of the $2-\mathrm{AG}$ on the $\beta 2$-containing $\mathrm{GABA}_{\mathrm{A}}$ receptors offers the potential for selective pharmacological intervention that would reduce motility and possibly affect sedation and state of anxiety [56]. Furthermore, it is shown that 2-AG acts synergistically with the neurosteroid tetrahydrodeoxycorticosterone (THDOC; 3a,21- 
dihydroxy-5 $\alpha$-pregnan-20-one) and modulates extrasynaptic receptors that respond to neurosteroids [55].

\section{Modulation of GABAA receptors by pharmacological agents}

$\mathrm{GABA}_{\mathrm{A}}$ receptors are targeted by many clinically important drugs. Namely, besides binding site(s) for $\mathrm{GABA}_{\mathrm{A}} \mathrm{GABA}_{\mathrm{A}}$ receptors possess binding sites for a variety of clinically important substances, such as benzodiazepines and benzodiazepine-site ligands, barbiturates, intravenous and volatile anesthetics, ethanol and neuroactive steroids, all of which achieve at least some of their pharmacological effects after binding to $\mathrm{GABA}_{\mathrm{A}}$ receptor complex $[6,17,57]$. These drugs modulate effects of GABA and affect GABAergic transmission, exerting a wide spectrum of pharmacological effects and inducing numerous conformational states of $\mathrm{GABA}_{\mathrm{A}}$ receptors.

Diverse approaches have been applied in last years to more precisely identify various binding sites on $\mathrm{GABA}_{\mathrm{A}}$ receptor complex, as this knowledge is prerequisite for the design of subtype specific, selective drugs of clinical relevance. Study performed on the comparative models of the extracellular and transmembrane domains of $\mathrm{GABA}_{\mathrm{A}}$ receptors in the agonistfree state has revealed that a loose packing of these domains results in a large amount of solvent-accessible space, probably offering a potential explanation for such complex pharmacology and great flexibility of $\mathrm{GABA}_{\mathrm{A}}$ receptors [58].

Drugs acting at benzodiazepine binding sites can only modulate $\mathrm{GABA}_{\mathrm{A}}$ receptors, while barbiturates, neuroactive steroids and anesthetics at higher concentrations are able to directly activate $\mathrm{GABA}_{\mathrm{A}}$ receptors in the absence of GABA [31,59-63]. Binding sites for all of these drugs are allosterically coupled. Therefore, drug that fits or binds to any of these multiple binding pockets induces conformational changes of the receptor complex and modulates GABA-elicited response [64,65]. For some of these multiple binding sites ligands have been identified, whereas for others sites, ligands are unknown. Similarly, the sites of action of large number of compounds that allosterically modulate $\mathrm{GABA}_{\mathrm{A}}$ receptors are still not identified [66].

Increased activity of $\mathrm{GABA}_{\mathrm{A}}$ receptor activity leads to anxiolysis, ataxia, myorelaxation, sedation, hypnosis, anesthesia and anterograde amnesia, whereas decrease in $\mathrm{GABA}_{\mathrm{A}}$ receptor activity leads to increased vigilance, memory enhancement, anxiety and seizures $[6,67]$. $\mathrm{GABA}_{\mathrm{A}}$ receptors are therefore widely used in the treatment of anxiety 
disorders, insomnia, epilepsy, restlessness, and aggressive behaviours [17,68]. Recently, Rudolph and Möhler [69] gave comprehensive overview of the role of $\mathrm{GABA}_{\mathrm{A}}$ receptor subtypes on cognitive and emotional behaviour, particularly to cognitive dysfunction and Down syndrome, anxiety disorders, depression, schizophrenia, and autism. They highlighted that a partial inverse agonist acting at the $\alpha 5$-subunit-containing $\mathrm{GABA}_{\mathrm{A}}$ receptors is in a clinical trial in individuals with Down syndrome. Substances that selectively reduce function of $\alpha 5$-containing $\mathrm{GABA}_{\mathrm{A}}$ receptors are considered as potential cognition enhancers for Alzheimer's syndrome and other dementia, consistent with genetic studies implicating $\mathrm{GABA}_{\mathrm{A}}$ receptors in learning performances [70]. With regard to anxiety disorders, nonsedative anxiolytics based on the modulation of $\alpha 2$ - and $\alpha 3$-subunit-containing $\mathrm{GABA}_{\mathrm{A}}$ receptors have been established in clinical proof-of-concept trials. Furthermore, Rudolph and Möhler [69] emphasized the GABA hypothesis of depression and new options for antidepressant drug development. They also pointed out that cognitive symptoms in schizophrenia are attributed to a cortical GABAergic deficit, and that dysfunctional GABAergic inhibition contributes to the pathophysiology of autism spectrum disorders.

Furthermore, the properties of $\mathrm{GABA}_{\mathrm{A}}$ receptors specific to interneurons may differ significantly from those found on projecting neurons, offering the possibility of developing interneuron-specific drugs that is of great therapeutic interest as more and more neurological and psychiatric disorders are linked to malfunction or deficits of interneurons [3]. Cells of glial origin also express $\mathrm{GABA}_{\mathrm{A}}$ receptor subunit isoforms and form functional ion channels that are modulated by classical $\mathrm{GABA}_{\mathrm{A}}$ receptor drugs, including diazepam and anesthetics etomidate and propofol [71].

\section{Effects of GABA and GABA agonists at $G A B A_{A}$ receptor}

Besides GABA, other compounds also act at GABA recognition sites. Muscimol, 4,5,6,7-tetrahydroisoxazolo(5,4-c)pyridine-3-ol (THIP, a bicyclic muscimol analog) and isoguvacine are structural analogs of GABA, and have direct GABA mimetic effects, while alkaloid bicuculline competitively antagonises effects of GABA at GABA binding sites. Muscimol has been widely used as a valuable tool to study pharmacology of $\mathrm{GABA}_{\mathrm{A}}$ receptors, and was the lead compound in the development of a range of GABAergic agents [72-74]. Behavioural effects of muscimol and THIP are preferentially mediated via highaffinity agonist binding sites at extrasynaptic receptors containing $\alpha 4$ and $\delta$ subunits. For 
THIP at high concentrations, the superagonistic behaviour on $\alpha 4 \beta 3 \delta$ receptors is achieved due to its ability to increase the duration of longer channel openings and their frequency, resulting in longer burst durations, while muscimol-related moderate superagonist behaviour is caused by reduced receptor desensitisation [75]. The ability to specifically increase the efficacy of extrasynaptic receptor activation by selected exogenous agonists might have important therapeutic implications, particularly under circumstances when synaptic inhibition is compromised, enabling manipulation of different components of inhibitory circuits [75-77]. Furthermore, it was found that chronic activation of $\mathrm{GABA}_{\mathrm{A}}$ receptors by muscimol may exert neuroprotective effects against $A \beta$-induced apoptotic neuronal death [78].

Radioligand binding studies indicated that GABA and GABA agonists stimulate binding of benzodiazepine agonists, and inhibit binding of inverse agonists at benzodiazepine binding site. Vice versa, GABA binding is stimulated by benzodiazepines, barbiturates, neuroactive steroids and anesthetics. Picrotoxin and other convulsants allosterically inhibit binding of GABA at $\mathrm{GABA}_{\mathrm{A}}$ receptors [79-83]. Studies with $\left[{ }^{3} \mathrm{H}\right]$ muscimol and $\left[{ }^{3} \mathrm{H}\right] \mathrm{GABA}$ have revealed two kinds of agonist binding sites on the $\mathrm{GABA}_{\mathrm{A}}$ receptor that differ in affinity. Biochemical and pharmacological experiments have suggested that high- and low-affinity sites might be interchangeable conformational variants of the same receptor complex. In most studies, functional responses to GABA have been observed only at micromolar concentrations, while nanomolar concentrations are needed to occupy the high-affinity binding sites. Hence, it is possible that the high-affinity sites represent a desensitized form of $\mathrm{GABA}_{\mathrm{A}}$ receptors or otherwise non-functional binding sites [76,84].

The binding site for $\mathrm{GABA}_{\text {at }} \mathrm{GABA}_{\mathrm{A}}$ receptor is located at the extracellular interface between the $\alpha$ and the $\beta$ subunit, and a number of amino acids residues in the binding pocket have been identified that are important for pharmacological activity, subtype selectivity, assembly, trafficking and surface expression [84-87]. At the major, and the best characterized subtype of $\mathrm{GABA}_{\mathrm{A}}$ receptor that is assembled from $\alpha, \beta$ and $\gamma$ subunits, there are two binding sites for GABA. When two molecules of GABA bind to receptor complex, the receptor channel opens, and chloride ions rush into the postsynaptic neuron. However, as one pair of these otherwise identical subunits is flanked by $\gamma$ and $\beta$ (site 1) and the other by $\alpha$ and $\gamma$ (site 2 ), different environments affect the binding sites. In $\alpha 1 \beta 2 \gamma 2$ receptors, site 2 has an approximately threefold higher affinity for GABA than site 1, whereas muscimol and bicuculline show some preference for site 1. Opening of the chloride channel also occurs for receptors occupied with a single agonist molecule but is promoted approximately 60 -fold in 
those occupied by two agonists [88]. After occupancy of GABA binding sites, the large portion of the receptor undergo conformational changes that trap agonist inside the binding pocket, a deep narrowing cleft that probably may constrict during channel gating [64].

The potency of GABA in opening chloride channels is determined by subunit composition. For example, in one study aimed to characterize the potency of GABA at human recombinant $\delta$-containing extrasynaptic $\mathrm{GABA}_{\mathrm{A}}$ receptors expressed in Xenopus oocytes, it is found that $\alpha 4 / \delta$-containing receptors display high sensitivity to GABA, with mid-nanomolar concentrations activating $\alpha 4 \beta 1 \delta$ and $\alpha 4 \beta 3 \delta$ receptors. In the majority of oocytes expressing $\alpha 4 \beta 3 \delta$ subtypes, GABA produced a biphasic concentration-response curve, and activated the receptor with low and high concentrations, while at $\alpha 4 \beta 2 \delta$ receptors, GABA exerted low micromolar activity. An analysis of 10 point mutations in the large $\mathrm{N}$-terminal extracellular domains in $\alpha 4 \beta 3 \delta$ receptors shows that GABA interacts with amino acids different to those reported for $\alpha 1 \beta 2 \gamma 2 \mathrm{GABA}_{\mathrm{A}}$ receptors suggesting that GABA may have different binding modes for extrasynaptic $\delta$-containing $\mathrm{GABA}_{\mathrm{A}}$ receptors compared to their synaptic counterparts [89].

\section{Effects of drugs acting at benzodiazepine binding sites at $\mathrm{GABA}_{\mathrm{A}}$ receptor}

Due to their pharmacological and clinical relevance, benzodiazepines have attracted much attention as allosteric modulators of $\mathrm{GABA}_{\mathrm{A}}$ receptors. Various ligands acting at benzodiazepine binding site can enhance (positive modulators or agonists) or reduce (negative modulators or inverse agonists) the actions of GABA on GABAergic transmission with a different range of efficacy (from full to partial). Antagonists are devoid of intrinsic activity, but can inhibit effects of both positive and negative modulators [6].

Benzodiazepines and other substances acting at the benzodiazepine binding site are the most commonly prescribed drugs in therapeutic use due to their desirable anxiolytic, myorelaxant, sedative/hypnotic and anticonvulsant effects. Classical benzodiazepines, such as diazepam and flunitrazepam, do not open channel directly, but allosterically potentiate activation of $\mathrm{GABA}_{\mathrm{A}}$ receptor containing either $\alpha 1,-2,-3$ or -5 subunits. This means that after their binding, conformational changes at the receptor confer to increased affinity for channel gating by GABA at both agonist sites. Accordingly, in electrophysiological recordings classical benzodiazepines do not affect the maximal current amplitude, but GABA 
concentrations required for channel opening are shifted to lower values. In contrast to them, negative allosteric modulators shift GABA concentration curve to the right [5].

The subunit composition of the $\mathrm{GABA}_{\mathrm{A}}$ receptor complex largely determines pharmacological properties at benzodiazepine binding site. In fact, pharmacological profile is predominantly determined by $\alpha$ and $\gamma$ subunits isoforms. It has been shown that different receptor conformations, in particular $\gamma \beta \alpha 1 \beta \alpha 6, \gamma \beta \alpha 6 \beta \alpha 1, \gamma \beta \alpha 1 \beta \alpha 1$ and $\gamma \beta \alpha 6 \beta \alpha 6$, have their own pharmacological signature and that diazepam efficacy is determined exclusively by the $\alpha$ - subunit neighbouring the $\gamma 2$-subunit [35]. The most applied concept is that the $\alpha 1 \beta x \gamma 2$ receptors, called type I BZ receptors, preferentially bind full benzodiazepine agonists with high affinity, while $\alpha 2 / 3 / 5 \beta x \gamma 2$-receptors, classified as type II BZ receptors, have approximately 10-fold lower affinity for benzodiazepine agonists [24,81]. Sedative, anterograde amnesic and partly anticonvulsant properties are attributed to $\alpha 1$-containing receptors, while the presence of $\alpha 2$ and/or $\alpha 3$ subunits determines anxiolytic and myorelaxant activity of benzodiazepines [90-92]. This means that compound that selectively modulates receptors with $\alpha 2$ and/or $\alpha 3$ subunits, but not $\alpha 1$-containing receptors, would be a nonsedating anxiolytic, suitable for the treatment of generalised anxiety disorder [93]. Receptors containing $\alpha 5$ subunits confer to learning and temporal and spatial memory. The $\alpha 5$ subunit of the $\mathrm{GABA}_{\mathrm{A}}$ receptor is localized mainly to the hippocampus of the mammalian brain. It is shown that the largely extrasynaptic $\alpha 5 \mathrm{GABA}_{\mathrm{A}}$ receptors in hippocampal pyramidal cells are implicated as control elements of the temporal association of threat cues in trace fear conditioning [94]. Furthermore, the $\alpha 5$-/- mice showed a significantly improved performance in a water maze model of spatial learning, indicating that $\alpha 5$-containing receptors play a key role in cognitive processes [95]. However, as pointed by Sigel and Steinmann [5], behaviour is a complex phenomenon, and caution is needed in an attempt to define the role of individual $\mathrm{GABA}_{\mathrm{A}}$ receptor subunits, as most probably several types of $\mathrm{GABA}_{\mathrm{A}}$ receptors determines even the simple behavioural traits. Receptors containing $\alpha 4$ and $\alpha 6$ subunits are generally thought as insensitive to classical benzodiazepine agonists [96,97], although they retain a high affinity for the partial inverse benzodiazepine agonist Ro 15-4513 [98]. Unusually, specific high-affinity binding of the benzodiazepine agonist flunitrazepam to $\alpha 6 \beta 2 \gamma 2$-containing $\mathrm{GABA}_{\mathrm{A}}$ receptors was shown [99], but flunitrazepam action on $\alpha 6 \beta 2 \gamma 2$-receptors was opposite to its action on $\alpha 1 \beta 2 \gamma 2$-receptors where it exhibits an inverse agonistic effect in a GABA-dependent manner. 
Benzodiazepines bind with high-affinity to a binding site located at the $\alpha / \gamma$ subunit interface in the extracellular domain of $\mathrm{GABA}_{\mathrm{A}}$ receptor $[65,100]$. The binding site for benzodiazepines is formed by one of $\alpha$ subunits $(\alpha 1, \alpha 2, \alpha 3$ or $\alpha 5)$ and a $\gamma$ subunit (typically the $\gamma 2$ subunit, which is present in approximately $90 \%$ of all $\mathrm{GABA}_{\mathrm{A}}$ receptors) [4]. Studies on recombinant $\mathrm{GABA}_{\mathrm{A}}$ receptors indicated that co-expression of $\alpha, \beta$ and $\gamma$ subunits is required for arrangement of high-affinity binding sites at $\mathrm{GABA}_{\mathrm{A}}$ receptor complex [101]. Hanson and Czajkowsky [102] have identified that Gln182-Arg197 region of $\gamma 2$ subunit is part of the allosteric pathway that allows propagation of structural changes induced by positive benzodiazepine modulators through the protein to the channel domain. Furthermore, several amino acid residues on $\alpha$ and $\gamma$ subunits have been identified that are crucial for benzodiazepine activity and form benzodiazepine binding pocket [86,103-105]. It is considered that antagonists bind in a pocket partly overlapping with the agonist site, although they can extend further into the solvent accessible cavity [106].

Richter et al. [107] described a binding mode for diazepam and analogs. By using this binding hypothesis and virtual screening approaches, they identified numerous known ligands of benzodiazepine-binding site from different structural classes and predicted potential new chemotypes for this site, thus demonstrating its suitability for drug discovery and structurebased drug design which is of major therapeutic importance. According to the model, although hundreds of ligands from different structural classes can bind to the benzodiazepinebinding sites, only a minority is bound to the same bioactive conformation as diazepam.

Evidence exists that some benzodiazepines can also bind to additional binding sites on $\mathrm{GABA}_{\mathrm{A}}$ receptor complex. Walters et al. [108] demonstrated that in the presence of low concentrations of GABA, diazepam produces a biphasic potentiation of $\alpha 1 \beta 2 \gamma 2$-receptor channels, with distinct components in the nanomolar and micromolar concentration ranges. Mutations at equivalent residues within the second transmembrane domains (TM2) of $\alpha, \beta$ and $\gamma$ subunits abolished only the micromolar component, while nanomolar component, which depends on the presence of $\gamma 2$ subunit, was not affected. Similarly, converse mutation of the corresponding TM2 residue and a TM3 residue within $\rho 1$ subunits confers diazepam sensitivity on homo-oligomeric $\rho 1$-receptor channels that are otherwise insensitive to benzodiazepines. Furthermore, effect of micromolar component on the GABA-induced current was not inhibited by flumazenil, an antagonist of benzodiazepine binding sites. As these transmembrane domains are important for effects of anesthetics, and taking into account anesthetic properties of diazepam, it might be that low potency modulation is elicited via anesthetic binding site [66]. 
In contrast to diazepam that act as positive allosteric modulator in both nanomolar and micromolar range, $\beta$-carbolines, such as methyl-6,7-dimethoxy-4-ethyl- $\beta$-carboline (DMCM), act as negative allosteric modulators at high affinity sites, but potentiate effects of GABA via the low-affinity binding sites [109]. The apparent reversal of inhibition and potentiation by high concentrations of DMCM is insensitive to flumazenil, $\beta 2 / 3$ subunit dependent, and probably elicited via the binding site for anticonvulsant loreclezole in the transmembrane domain. Moreover, Baur et al. [110] found evidence for the presence of a third site for benzodiazepines that prevents modulation of $\mathrm{GABA}_{\mathrm{A}}$ receptors via the classical benzodiazepine site. The novel site potentially contributes to the high degree of safety to some of these drugs. Their results indicate that this site may be located at the $\alpha / \beta$ subunit interface pseudo-symmetrically to the site for classical benzodiazepines located at the $\alpha / \gamma$ interface.

In addition, it is found that the specific effects of imidazobenzodiazepine Ro15-4513 in antagonizing ethanol-stimulated ${ }^{36} \mathrm{Cl}^{-}$uptake and behaviour can be completely blocked by benzodiazepine receptor antagonists. As other benzodiazepine receptor inverse agonists fail to antagonize the actions of ethanol in vitro or in vivo, a novel binding site for Ro15-4513 is also hypothesized [111]. Hanchar et al. [112] demonstrated that extrasynaptic $\delta$ subunit-containing receptors bind the imidazo-benzodiazepines flumazenil and Ro15-4513 with high affinity, contrary to the widely held belief that these receptors are benzodiazepine insensitive. Recently, it was identified that in addition to benzodiazepine binding site, Ro15-4513 interacts with high affinity to sites at the $\alpha 4 / 6+\beta 3$ - interface (each subunit has a plus and minus side determined by the absolute arrangement of subunits around central pore) and thus inhibits ethanol effects [98].

As for some potential binding sites no interacting drugs have been identified, Ramerstorfer et al. [113] established a steric hindrance procedure for the identification of drugs acting at the extracellular $\alpha 1+\beta 3$ - interface, which is homologous to the benzodiazepine binding site at the $\alpha 1+\gamma 2$ - interface, while GABA-binding sites are located at the $\beta+\alpha-$ interface [66]. Among screened compounds, anxiolytic pyrazoloquinoline 2-pmethoxyphenylpyrazolo[4,3-c]quinolin-3(5H)-one (CGS 9895) was able to enhance GABAinduced currents at $\alpha 1 \beta 3$ receptors from rat. Thus, at nanomolar concentrations CGS 9895 behaves as an antagonist of high-affinity, benzodiazepine binding site, but exerts a lowpotency positive modulatory action at the extracellular $\alpha+\beta$ - interface of $\alpha 1 \beta 3 \gamma 2$ and $\alpha 1 \beta 3$ receptors. Other experiments indicated that the CGS 9895 effect was dependent on $\alpha$ and $\beta$ subunit isoforms forming the interface. Since CGS 9895, even at high concentrations, was only able to enhance GABA-induced currents but not directly activate these receptors, it is 
likely that drugs acting via the $\alpha+\beta$ - interface only have GABA-modulatory properties, like the benzodiazepines do. In contrast to benzodiazepines, these drugs will interact with receptors composed of $\alpha \beta, \alpha \beta \gamma$, and $\alpha \beta \delta$ subunits. Hence, they would exhibit a much broader anticonvulsive action than benzodiazepines, which might be of clinical importance for the treatment of epilepsy and development of subtype-selective drugs.

Based on results obtained with crystal structure of ELIC, prokaryotic homolog of $\mathrm{GABA}_{\mathrm{A}}$ receptor, it is possible that at least some benzodiazepines, such as flurazepam, may directly interact with the GABA-binding site at $\beta+\alpha$ - interface at high concentration and displace GABA from its binding site, although these effects are observed only at high concentrations and further experiments are needed to confirm if this site has a functional role in $\mathrm{GABA}_{\mathrm{A}}$ receptors [66,114].

Unfortunately, despite their proven clinical efficacy, positive modulators of benzodiazepine binding sites at $\mathrm{GABA}_{\mathrm{A}}$ receptor possess a relatively narrow window between doses that produce anxiolytic effects and those that cause sedation, and are associated with the development of tolerance and physical and psychological dependence and a potential for abuse [115-117]. Hence, strategy to resolve the disadvantages of classical full agonists was directed toward development of partial agonists with lower intrinsic efficacy. A number of non-selective partial agonists with reduced intrinsic efficacy, including bretazenil, pazinaclone and abecarnil, were described. In general, although they have a large window between anxiolytic and sedative doses and their dependence and abuse liabilities were much lower, they failed to translate into clinical benefit [93]. More recently, the imidazolone derivatives imepitoin was shown to act as low-affinity partial agonist at the benzodiazepine site of the $\mathrm{GABA}_{\mathrm{A}}$ receptor, and was approved for the treatment of epilepsy in epileptic dogs due to its more favorable pharmacokinetic profile in dogs versus humans, reactivating again the interest for partial benzodiazepine agonists for the treatments of human epilepsy [118].

Regarding development of tolerance and dependence to benzodiazepine-site ligands after prolonged administration, diverse effects at the molecular and cellular level have been described, including receptor desensitization and changes in the number and subunit composition of surface $\mathrm{GABA}_{\mathrm{A}}$ receptors, often leading to decreased ability of benzodiazepines to potentiate effects of GABA [17,119-124].

\section{Effects of convulsants at $\mathrm{GABA}_{\mathrm{A}}$ receptor}


Very early picrotoxin was identified as a noncompetitive inhibitor of $\mathrm{GABA}_{\mathrm{A}}$ receptor. Binding studies further revealed that numerous compounds from heterogeneous chemical classes posses affinity for picrotoxin-binding sites, including $t$ butylbicyclophosphorothionate (TBPS), $t$-butylbicycloorthobenzoate (TBOB), pentylenetetrazole, and some insecticides (such as dieldrin and lindane). They inhibit GABAinduced influx of chloride ions acting as allosteric antagonists at $\mathrm{GABA}_{\mathrm{A}}$ receptor complex [125-128].

TBPS partially and allosterically inhibits binding of GABA and positive modulators of $\mathrm{GABA}_{\mathrm{A}}$ receptors, but facilitates binding of negative modulators. Similarly, modulators of $\mathrm{GABA}_{A}$ receptor function affect $\left[{ }^{35} \mathrm{~S}\right] \mathrm{TBPS}$ binding. GABA exhibits biphasic effect on the allosteric modulation of $\left[{ }^{35} \mathrm{~S}\right] \mathrm{TBPS}$ binding. Thus, $\left[{ }^{35} \mathrm{~S}\right] \mathrm{TBPS}$ binding was allosterically inhibited by high concentrations of GABA, GABA agonists and other positive modulators (various benzodiazepine receptor agonists, anesthetics and pentobarbital) and promoted in the presence of negative modulators such as ethyl- $\beta$-carboline-3carboxylate ( $\beta$-CCE). On the contrary, GABA applied at low concentrations enhanced $\left[{ }^{35}\right.$ S]TBPS binding [6,36,129-132]. In addition, the effects of the anesthetic steroid and pentobarbital on $\left[{ }^{35} \mathrm{~S}\right] \mathrm{TBPS}$ binding were markedly altered by GABA, which at $2 \mu \mathrm{M}$ increased their maximal effects and half-maximal concentrations. On the contrary, GABA did not affect changes in $\left[{ }^{35} \mathrm{~S}\right] \mathrm{TBPS}$ binding produced by various benzodiazepine receptor agonists, indicating more pronounced functional coupling of the GABA sites with those for the steroid and the barbiturate, as compared with the benzodiazepine site. Hence, it appears that the degree of $\left[{ }^{35} \mathrm{~S}\right] \mathrm{TBPS}$ binding in the presence of $\mathrm{GABA}$ reflects the functional state of $\mathrm{GABA}_{\mathrm{A}}$ receptors and may be useful for characterization of allosteric interactions between various sites on the receptor $[6,133]$.

Inhibitory effects of GABA on $\left[{ }^{35} \mathrm{~S}\right] \mathrm{TBPS}$ binding are determined by $\alpha$ subunit isoform. It has been shown that expression of recombinant $\alpha 6 \beta 2 \gamma 2 \mathrm{GABA}_{\mathrm{A}}$ receptors produces $\left[{ }^{35} \mathrm{~S}\right] \mathrm{TBPS}$ binding sites that are about 10 -fold more sensitive to inhibition by GABA than were those inherent to $\alpha 1 \beta 2 \gamma 2$ GABA $_{A}$ receptors. Similarly, the neurosteroid $5 \alpha-$ pregnan-3 $\alpha$-ol-20-one (allopregnanolone) affected the binding in both $\alpha 1 \beta 2 \gamma 2$ and $\alpha 6 \beta 2 \gamma 2$ receptors, but inhibition was greater in $\alpha 6$-containing than in $\alpha 1$-containing receptors, also suggesting differential coupling of both GABA and neurosteroid sites with the convulsant site [134].

At first, it was suggested that picrotoxin's site of action is probably within the channel pore as mutations in TM2 domains (that form chloride channels) produced currents that were insensitive to picrotoxin [135]. By convention, Cys-loop receptor TM2 residues are numbered 
from intracellular 0 to extracellular 20 positions. Although the exact location of picrotoxin binding to ionophore is still unknown, its sensitivity to mutations in residues $2 / 3$ and 6 of TM2 indicates that the site contains residues 2-6. In particular, it is suggested that picrotoxin enters deep inside the ionophore pore, binds with its hydrophobic moiety to residue 2 of TM2 (close to the pore) and forms hydrogen bounds with residue 6 in the middle of TM2. Residue 15 is probably important for interplay between GABA and picrotoxin binding sites. Other studies implicated residues 9 and 15 in the regulation of channel properties, including desensitization, stabilization of open states and gating. This indirectly supports the possibility of a second "modulatory" (allosteric) binding site of picrotoxin including residues 15-19 [128].

Dillon et al. [136] provided evidence that picrotoxin and TBPS interact with GABAbound and -resting receptors, but their affinity for GABA-bound receptors is about 10 times greater, largely due to a markedly increased association rate to the multi-liganded receptors. Accordingly, TBPS and picrotoxin are considered as open channel blockers. However, $\left[{ }^{35} \mathrm{~S}\right]$ TBPS binds to recombinant receptors in the absence of GABA [130]. Hence, it does not gain access to its binding site via the open pore but through alternative routes regulated from the agonist binding site [137]. It is shown that picrotoxin displaceable $\left[{ }^{35} \mathrm{~S}\right] \mathrm{TBPS}$ binding to $\alpha 1 \beta 2 \gamma 2 \mathrm{GABA}_{\mathrm{A}}$ receptors might occur in the absence of GABA, suggesting that access to the binding site is independent of activation. In fact, bicuculline-sensitive spontaneous gating contributes to $\left[{ }^{35} \mathrm{~S}\right] \mathrm{TBPS}$ binding in the absence of GABA by providing access to the channel. Accordingly, a decrease in a spontaneous gating reduces accessibility of TBPS to its binding site [132]. GABA application during picrotoxin or TBPS administration enhanced $\alpha 1 \beta 2 \gamma 2$ receptor blockade, and this GABA-dependent component of TBPS blockade accounts for the stimulation of $\left[{ }^{35} \mathrm{~S}\right] \mathrm{TBPS}$ binding to $\alpha 1 \beta 2 \gamma 2$ receptors seen with low concentrations of GABA, while application of GABA at concentrations that cause significant steady-state desensitization reduces $\left[{ }^{35} \mathrm{~S}\right] \mathrm{TBPS}$ binding [132].

\section{Effects of anesthetics at $\mathrm{GABA}_{\mathrm{A}}$ receptor}

General anesthetics are used to induce a reversible loss of consciousness in surgical patients and to relieve pain. $\mathrm{GABA}_{\mathrm{A}}$ receptors are the major site of action of clinically used intravenous anesthetics such as etomidate, propofol, barbiturates and neuroactive steroids. On the other hand, clinically used volatile anesthetics such as isoflurane and enflurane, and long- 
chain alcohols, presumably act via a multitude of targets, $\mathrm{GABA}_{\mathrm{A}}$ receptors being just one of them $[4,63,138,139]$.

In general, $\mathrm{GABA}_{\mathrm{A}}$ receptors are positively modulated by clinical doses of anesthetics, while at higher concentrations anesthetics can directly activate $\mathrm{GABA}_{\mathrm{A}}$ receptors $[63,140]$. Accordingly, many studies were aimed to identify binding site(s) for anesthetics on $\mathrm{GABA}_{\mathrm{A}}$ receptors, which are generally considered as the main target for propofol and etomidate action as already mentioned. Belelli and co-authors [141] have shown that the ability of etomidate to modulate and activate $\mathrm{GABA}_{\mathrm{A}}$ receptors in vitro is uniquely dependent upon the $\beta$ subunit subtype present within the receptor, i.e. receptors containing $\beta 2$ - or $\beta 3-$, but not $\beta 1$ subunit, are highly sensitive to etomidate. They identified a region distal to the extracellular Nterminal domain as a determinant of the selectivity of etomidate: mutation of Asn present within the channel domain of the $\beta 3$ subunit to Ser (the homologous residue in $\beta 1$ ) strongly suppressed the GABA-modulatory and GABA-mimetic effects of etomidate. Later, it was confirmed that the same point mutation (Asn265Met) completely abolished the suppression of noxious-evoked movements in response to propofol and etomidate in a knock-in mouse, while only slightly decreased in response to volatile anesthetics enflurane and halothane. Mice also displayed a profound reduction in the loss of righting reflex duration (a surrogate for loss of consciousness) in response to intravenous but not volatile anesthetics. Accordingly, electrophysiological recordings revealed that anesthetic agents were significantly less effective in enhancing GABA-induced currents in cortical brain slices derived from mutant mice, thus identifying the key molecular determinant of behavioural responses evoked by intravenous anesthetics [142].

Studies on recombinant receptors have revealed that isoforms of $\alpha, \gamma$ and $\delta$ subunits affect propofol modulation of the $\mathrm{GABA}_{\mathrm{A}}$ receptor, although it seems likely that the propofol binding site involves the $\beta$ subunit (see below). In order to investigate the role of $\alpha$ subunit in the modulatory effects of propofol, Krasowski et al. [143] used whole-cell patch clamp recordings from cells expressing only $\alpha 1 \beta 3 \gamma 2$ or $\alpha 6 \beta 3 \gamma 2$ subtypes, and found that at clinically relevant concentrations, propofol potentiated submaximal GABA currents in $\alpha 1 \beta 3 \gamma 2$ receptors to a far greater degree than in $\alpha 6 \beta 3 \gamma 2$ receptors. Isoform of $\alpha$ subunit influenced the efficacy of propofol for modulation, but not its potency. On the contrary, direct gating of the chloride channel was significantly larger in the $\alpha 6 \beta 3 \gamma 2$ receptors. A same trend for potentiation and direct gating was observed for other anesthetics. Similarly, pharmacological properties of human recombinant $\mathrm{GABA}_{\mathrm{A}}$ receptors were studied in Xenopus oocytes expressing $\alpha 1 \beta 2$, 
$\alpha 1 \beta 2 \gamma 2 \mathrm{~L}$, or $\alpha 2 \beta 2 \gamma 2 \mathrm{~L}$ receptor isoforms. In all receptor isoforms tested, propofol potentiated the GABA-activated currents in a concentration-dependent manner, and was able to directly activate all three receptor isoforms. Addition of the $\gamma 2 \mathrm{~L}$ subunit to the $\alpha 1 \beta 2$ isoform reduced receptor sensitivity to direct activation, while replacement of the $\alpha 1$-subunit with the $\alpha 2$ subunit increased receptor sensitivity to propofol's direct effects, indicating that isoforms of $\alpha$ and $\gamma$ subunits have the ability to influence both the direct and modulatory actions of propofol on $\mathrm{GABA}_{\mathrm{A}}$ receptor function [144]. Jones et al. [140] reported that $\gamma 2$ subunit is not a prerequisite for activation of $\mathrm{GABA}_{\mathrm{A}}$ receptors by propofol or for its potentiation of GABAactivated currents, but showed that it may contribute to the efficacy of propofol as a $\mathrm{GABA}_{\mathrm{A}}$ receptor activator. Furthermore, the findings that propofol reduced desensitization and prolonged deactivation of receptors containing $\gamma 2 \mathrm{~L}$ subunit and enhanced peak currents or prolonged deactivation of receptors containing $\delta$ subunit suggest that propofol-induced enhancement of both phasic and tonic inhibition may contribute to its anesthetic effect in the brain [145]. In accordance with mentioned studies, mutations in $\alpha$ and $\gamma$ subunits change modulatory effects of propofol at the $\mathrm{GABA}_{\mathrm{A}}$ receptors [146,147], while particular residues in $\beta$ subunits, distributed throughout the membrane-spanning region of the receptor, as well as in the extracellular domain, determine the propofol's actions. Thus, a point mutation in the $\beta 1$ subunit (Met286Trp) abolished potentiation of GABA by propofol, but did not alter direct activation of the receptor by high concentrations of propofol [148]. The same mutation had the same effect in the $\beta 2$ subunit, probably by altering the dimensions of a binding pocket for propofol and related alkylphenol general anesthetics [149]. One mutation in $\beta 2$ subunit (Tyr444Trp) was particularly interesting, as it selectively suppressed the ability of propofol to enhance receptor function, while retaining normal sensitivity to etomidate [150].

Although various anesthetics do not bind to the same binding site and exhibit distinct structural requirements for modulatory and direct actions, it seems that main sites of action are located close to each other, within the transmembrane domain [151]. The influence of the large intracellular loop in propofol sensitivity has also been recognized. Moraga-Cid et al. [147] have shown that mutation of a conserved Phe385 residue within the $\alpha 1$ large intracellular loop significantly reduced propofol enhancement, although propofolhyposensitive mutant receptors retained their sensitivity to other allosteric modulators such as alcohols, etomidate, trichloroethanol, and isoflurane. At the single-channel level, the ability of propofol to increase open probability was significantly reduced, altogether suggesting a new role of the large intracellular loop in allosteric modulation, and providing new insight into the propofol-mediated modulation of $\mathrm{GABA}_{\mathrm{A}}$ receptor complex. By using a novel propofol 
analogue photolabeling reagent, Yip et al. [152] have identified a novel binding site for propofol in $\beta 3$ homopentamers and $\alpha 1 \beta 3$ heteropentamers. The binding site is located within the $\beta$ subunit, at the interface between the transmembrane domains and the extracellular domain, and lies close to known determinants of anesthetic sensitivity in transmembrane segments TM1 and TM2.

The similar approach was used to determine binding site for etomidate. By using radiolabeled, photoreactive etomidate analogs, residues $\alpha$ Met-236 and $\beta$ Met-286 in the $\alpha \mathrm{TM} 1$ and $\beta$ TM3 transmembrane helices, were identified as a part of single binding pocket in the transmembrane domain at the $\beta+\alpha$ - interface, close to the extracellular domain, bellow the GABA-binding site. Such localization of the etomidate binding site to an inter-subunit, not an intra-subunit binding pocket was an interesting finding, suggesting that binding sites at subunit interfaces may be a feature not only for GABA and benzodiazepines, but also for etomidate and other anesthetics [153,154]. As photolabeled etomidate analog was also displaced by isoflurane, $\mathrm{Li}$ et al. [139] suggested that inhalation anesthetics also interact with this binding site. More precisely, in their study photolabeling was inhibited by low millimolar anesthetic concentrations of propofol, barbiturates, and isoflurane, but not by octanol or ethanol. Inhibition by barbiturates and propofol was only partial, consistent with allosteric interactions, whereas isoflurane inhibition was nearly complete, suggesting competitive interactions.

\section{Effects of barbiturates at GABAA receptor}

Response of $\mathrm{GABA}_{\mathrm{A}}$ receptors may also be modulated by barbiturates. They have been used in the past due to their anticonvulsant, anxiolytic, sedative, and hypnotic actions, but they exert serious side effects, including profound depression of CNS activity with the induction of pronounced sedation, cognitive slowing or confusion, hyperactivity in children and a lethal risk in a case of overdose [155-157].

As they bind to $\mathrm{GABA}_{\mathrm{A}}$ receptor with low affinity, most of their actions have been analysed indirectly by studying interactions with other binding sites. Barbiturates enhance binding of GABA and benzodiazepines, whereas inhibit binding at convulsant binding site [158]. Depending on the concentration, barbiturates act in three different ways, and their effects are proportional to anesthetic potency. At low $\mu \mathrm{M}$ (sub-anesthetic) concentrations they potentiate GABA-induced effects (modulatory effect) and prolong duration of open conformation of chloride channel, possibly by stabilizing open state(s). In higher $\mu \mathrm{M}$ 
(anesthetic) concentrations (app. $>50 \mu \mathrm{M}$ ) they directly open chloride channel (agonistic effect), whereas at very high $\mathrm{mM}$ concentrations block GABA-induced current (inhibitory effect) $[159,160]$. More precisely, when co-applied with low concentrations of GABA, barbiturates increased the mean open time. The increase in channel open time results in greater chloride current flux and increased likelihood that channel openings will summate, producing larger inhibitory currents [157]. In the absence of GABA, high concentrations of barbiturates may directly activate $\mathrm{GABA}_{\mathrm{A}}$ receptor chloride currents, although with lower efficacy than GABA [60]. All these effects are probably mediated by separate mechanisms. In support of this conclusion, it was demonstrated that mutation of Thr262 in the transmembrane domain of $\beta 1$ subunits at $\alpha 1 \beta 1$ recombinant $\mathrm{GABA}_{\mathrm{A}}$ receptors abolished modulatory effect, without affecting direct agonistic or inhibitory effects of pentobarbital [161].

Although barbiturate sensitivity does not require a specific subunit composition, their effects are also determined by subunit composition [57,157]. Isoforms of $\alpha$ subunit affect efficacy, but not affinity of barbiturates in potentiation of GABA response. In contrast to benzodiazepines that are ineffective at $\mathrm{GABA}_{\mathrm{A}}$ receptors containing $\alpha 4$ or $\alpha 6$ subunit, barbiturates elicit modulatory effects at receptors containing these isoforms [97,159], and the isoform of $\alpha$ subunit influences the level of potentiation [162]. Related to agonistic activity, the type of $\alpha$ subunit present determines both the degree of affinity and efficacy observed. Receptors containing $\alpha 6$ isoform produce maximum direct response to barbiturate pentobarbitone, larger than that obtainable with maximum GABA, and larger than that obtainable with other $\alpha$ subunits. $\mathrm{GABA}_{\mathrm{A}}$ receptors containing $\alpha 6$ subunits also have higher affinity for direct activation by pentobarbitone. Furthermore, the direct effect of pentobarbitone can be blocked by picrotoxin, but not by competitive antagonists, such as bicuculline [97,159]. Surprisingly, unlike receptors containing $\alpha 6$ isoform, $\alpha 4 \beta 1 \gamma 2$ receptors did not elicit any direct activation of $\mathrm{GABA}_{\mathrm{A}}$ receptors by pentobarbital [97].

Some amino acid residues have been identified with major impact on barbiturate activity. An invariant proline residue in transmembrane domain TM1 is included in a consensus motif of all $\mathrm{GABA}_{\mathrm{A}}$ receptor subunits. Proline in TM1 segment of $\beta 1$ subunit affects the linkage between GABA binding and channel gating and is critical for barbiturate enhancement at recombinant $\mathrm{GABA}_{\mathrm{A}}$ receptors, without affecting enhancement by diazepam or neurosteroid alfaxalone [163]. Gly219 near the TM1 at $\beta 2$ subunit is also identified as important for allosteric (modulatory) effects of pentobarbital since pentobarbital-induced enhancement of $\left[{ }^{3} \mathrm{H}\right]$ muscimol and $\left[{ }^{3} \mathrm{H}\right]$ flunitrazepam binding in receptors containing the $\beta_{2}$ (Gly219Phe) point mutation displayed a significantly reduced efficacy in modulation. 
Furthermore, functional analysis of pentobarbital-enhanced GABA currents recorded with whole-cell patch clamp demonstrated that this mutation eliminates the potentiating effect of the anesthetic. Interestingly, the $\alpha 1 \beta 2($ Gly219Phe) $\gamma 2$ receptors also were more sensitive to direct channel activation by pentobarbital, suggesting that Gly219 may be important for conformational or allosteric interactions of channel gating by GABA and barbiturates [164].

Chiara et al. [165] used a photoreactive barbiturate analog to determine residues important for barbiturate binding site. It photolabeled sites at the $\alpha+\beta$ - and $\gamma+\beta$ - subunit interfaces in the transmembrane domain, near the synaptic side. These binding sites are distinct but homologous to the etomidate sites at the two $\beta+\alpha$ - subunit interfaces, as all are located at the same depth in the transmembrane domain. They demonstrated that photoreactive barbiturate and etomidate derivatives are highly selective for their own sites, indicating that there are two structurally related, but pharmacologically distinct, classes of inter-subunit general anesthetic-binding sites in the transmembrane domain of human $\alpha 1 \beta 3 \gamma 2$ $\mathrm{GABA}_{\mathrm{A}}$ receptors. They hypothesized that binding at any of these homologous inter-subunit sites is sufficient for anesthetic action. Namely, a wide range of general anesthetic structures target these four sites but with variable selectivity, which offers an explanation of the puzzling lack of well defined structure-activity relationships among general anesthetics. More importantly, these findings indicate that it may be possible to synthesize general anesthetics with specificity for sites between specific subunits in the transmembrane domain of pentameric $\mathrm{GABA}_{\mathrm{A}}$ receptors, with a hope to target specific nerve pathways and behaviours in a subunit-dependent manner in the future [165].

\section{Effects of neurosteroids at GABAA receptors}

Inhibitory neurotransmission mediated by $\mathrm{GABA}_{\mathrm{A}}$ receptors can be modulated by endogenous neurosteroids, mostly metabolites of progesterone and deoxycorticosterine, including allopregnanolone and tetrahydrodeoxycorticosterone (THDOC). In general, they potently enhance function of synaptic and extrasynaptic $\mathrm{GABA}_{\mathrm{A}}$ receptors by an allosteric mechanism [31,40,166,167]. Neurosteroids possess distinct, characteristic effects on the membrane potential and current conductance mainly via potentiation of $\mathrm{GABA}_{\mathrm{A}}$ receptors at low doses, and direct activation of receptor chloride channel at higher concentrations. As a results, upon administration neurosteroids exert anxiolytic, analgesic, anticonvulsive, sedative and hypnotic effects, while applied at higher doses may induce a state of general anesthesia 
[40,168-171]. Although the most important effects of neurosteroids are mediated via GABA $_{\mathrm{A}}$ receptors, they also exert various effects on an array of ligand-gated ion channels and distinct G-protein-coupled receptors via nongenomic mechanisms, including the $N$-methyl-Daspartate (NMDA), alpha-amino-3-hydroxy-5-methyl-4-isoxazole-propionic acid (AMPA), kainate, glycine, serotonin, sigma type-1, and nicotinic acetylcholine receptors [156,172]. Besides modulation of diverse receptors, the other functions attributed to specific neurosteroids include neuroprotection, for example against glutamate-induced excitotoxicity, and induction of neurite outgrowth, dendritic spines and synaptogenesis, and contribution to the behavioural effects of psychoactive drugs [49,51,173-175].

As emphasized before, neurosteroids exhibit two modes of action at $\mathrm{GABA}_{\mathrm{A}}$ receptors. They allosterically modulate channel opening, and at high concentrations act as GABA-mimetics and directly open the chloride channel $[31,53,176]$. Two discrete binding sites in the receptor's transmembrane domains have been identified that mediate the potentiating and direct activation effects of neurosteroids. Neurosteroids potentiate GABA responses from a cavity formed by the $\alpha$-subunit transmembrane domains, while direct receptor activation is achieved by interfacial residues between $\alpha$ and $\beta$ subunits and is additionally enhanced by steroid binding to the potentiation site, indicating that activation of $\mathrm{GABA}_{\mathrm{A}}$ receptors by neurosteroids relies on the occupancy of both sites [177]. Further work provided a more detailed kinetic and pharmacological characterization of the effects of mutations on channel activation and modulation by neurosteroids, leading to a model where residues in the TM1 membrane-spanning domain shape the binding surface to accommodate a variety of structurally distinct neurosteroids [178]. The potentiating effect of neurosteroids can be mediated by steroid interactions with its site within the same $\beta-\alpha$ pair that mediates receptor activation as well as the opposite $\beta$ - $\alpha$ pair [179]. Chisary et al. [180] have shown that neurosteroids require a membranous route of access to transmembrane-domain binding sites that might have implications for the design of novel neuroactive steroids because their lipid solubility and related accessibility are probably the key determinants of receptor modulation [180]. This also suggests that by virtue of their high lipid solubility, $\mu \mathrm{M}$ concentrations of neurosteroids may be achieved locally [31].

Neuroactive steroids may act both as positive and negative modulators of $\mathrm{GABA}_{\mathrm{A}}$ receptor function. Applied at concentrations below $300 \mathrm{nM}$, they are positive allosteric neuromodulators as they facilitate conformational transition of the GABA-gated chloride channel to an open state, increase mean channel open time and consequently increase GABAelicited chloride currents [49,131,181-183]. Furthermore, they modulate binding of GABA 
agonists, increase binding of positive modulators at benzodiazepine binding sites, and enhance TBPS binding in the absence of GABA [184-187]. On the contrary, sulphated endogenous steroids like pregnenolone sulphate and dehydroepiandrosterone sulphate (DHEAS) act as negative modulators at steroid binding site when applied at $\mu \mathrm{M}$ concentrations [59]. For various neuroactive steroids sulfation at C-3 reverses the direction of modulation from positive to negative, suggesting that sulfation could be an important control point for the activity of endogenous neurosteroids. As interactions of positive and negative steroid modulators are not competitive, they probably act via distinct binding sites at $\mathrm{GABA}_{\mathrm{A}}$ receptor. This implies that negative and positive steroid modulators can act independently or coordinately to regulate GABA-mediated inhibition in the CNS [188]. Antagonistic neurosteroids may shorten the channel open time and enhance GABA-induced desensitization [6].

Similarly to other binding sites, subunit assembly determines sensitivity and pharmacological effects of neuroactive steroids. Studies on recombinant $\mathrm{GABA}_{\mathrm{A}}$ receptors have revealed that presence of $\delta$ subunit confers increases sensitivity to neurosteroid modulation by affecting intrinsic gating and desensitization kinetics [181,189]. Thus, at concentrations known to occur in vivo, neuroactive steroids specifically enhance a tonic inhibitory conductance in central neurons that is mediated by extrasynaptic $\delta$ subunitcontaining $\mathrm{GABA}_{\mathrm{A}}$ receptors [190]. In addition, expression of extrasynaptic $\mathrm{GABA}_{\mathrm{A}}$ receptors is dynamically regulated by neuroactive steroids. For example, it is suggested that neuroactive steroids mediate a stress-induced enhancement in the expression of $\alpha 4 \beta \delta$ receptors, probably contributing to observed stress-related memory impairment $[41,44,191]$. Potency and efficacy of neuroactive steroids is also determined by other subunits. Although these differences are not very pronounced, even small differences in receptor sensitivity might be physiologically relevant. Namely, allopregnanolone concentrations in plasma are 3-10 nM in physiological conditions, and increase only to 30-60 nM during stress [168].

Interestingly, it is confirmed that endogenous neurosteroids profoundly affect neuronal activity at particular receptor isoform. For example, it is shown that $\alpha 1 \beta 2 \delta$ subtype of $\mathrm{GABA}_{\mathrm{A}}$ receptors presumably expressed in the forebrain, exhibits an extremely small GABAmediated current in the absence of the modulator, but in the presence of THDOC exerts a profound inhibitory influence on neuronal activity by increasing maximum current amplitude and decreasing half-maximal concentration $\left(\mathrm{EC}_{50}\right)$ of GABA [192]. Hence, depending on the subunit composition, GABA-modulatory effects of physiological levels of the neurosteroid are not uniformly experienced throughout the CNS, or even within the same brain region. In 
addition, these modulatory effects are determined by the phosphorylation status of the $\mathrm{GABA}_{\mathrm{A}}$ receptor, or associated proteins, and by local steroid metabolism [31,49,54,193].

As endogenous ligands, neuroactive steroids may modulate diverse physiological and pathophysiological conditions, regulating $\mathrm{GABA}_{\mathrm{A}}$ receptor-associated functions and behaviour. Altered neurosteroid levels are associated with psychiatric and neurological disorders, including premenstrual dysphoric disorder, premenstrual syndrome, menstrual migraine, postpartum depression, pain disorder, catamenial epilepsy, major depression, schizophrenia, alcohol dependence and anxiety [51,177,194]. The pathogenesis of these diseases remains unclear, partly due to the lack of useful animal models to study such complex disorders [46]. As mentioned before, pregnancy is associated with a pronounced enhancement in progesterone-derived neurosteroid levels, with sharp decline after delivery. Because neuroactive steroids exert anxiolytic effects, neurosteroid withdrawal could play role in the pathophysiology of postpartum depression [195]. Synthetic neurosteroids that exerts better bioavailability and efficacy, as well as drugs that enhance neurosteroid synthesis and lack unwarranted side effects of benzodiazepines, are therefore considered as potential therapeutics in the treatment of anxiety, epilepsy and other brain disorders [156,195-197].

\section{Effects of ethanol at $\mathrm{GABA}_{\mathrm{A}}$ receptors}

Ethanol is often classified as modulator of $\mathrm{GABA}_{\mathrm{A}}$ receptor activity. It is without doubt that very high concentrations of ethanol modulate activity of diverse membrane proteins, including $\mathrm{GABA}_{\mathrm{A}}$ receptors [198]. However, it is not quite clear whether social ethanol intake $(<20 \mathrm{mM})$ really exerts effects on human behaviour via $\mathrm{GABA}_{\mathrm{A}}$ receptors [5]. Wallner and co-authors [199] have demonstrated that $\mathrm{GABA}_{\mathrm{A}}$ receptors might be enhanced by ethanol concentrations that are reachable by moderate, social consumption. They found that $\mathrm{GABA}_{\mathrm{A}}$ receptors responsive to these low concentrations require presence of $\delta$-subunit, which is thought to be associated exclusively with $\alpha 4-$ and $\alpha 6$-subunits, and the $\beta 3$-subunit. Their finding also suggests that extrasynaptic $\mathrm{GABA}_{\mathrm{A}}$ receptors are primary targets for ethanol. Later, Borghese and co-workers [198] failed to replicate the sensitivity of $\alpha 4 \beta 3 \delta$ $\mathrm{GABA}_{\mathrm{A}}$ receptors to low concentrations of ethanol at rat and human recombinant $\mathrm{GABA}_{\mathrm{A}}$ receptors expressed in Xenopus oocytes. In addition, in their study ethanol at $30 \mathrm{mM}$ concentration did not affect tonic GABA-mediated currents in dentate gyrus reported to be mediated by $\alpha 4 \beta 3 \delta$ subtype of $\mathrm{GABA}_{\mathrm{A}}$ receptors. Similarly, in another study, $\alpha 6 \beta 3 \delta \mathrm{GABA}_{\mathrm{A}}$ 
receptors were expressed in Xenopus oocytes and were not modulated by physiological concentrations (up to $30 \mathrm{mM}$ ) of ethanol [200].

On the other hand, prolonged ethanol consumption that leads to the development of alcohol dependence induces changes of $\mathrm{GABA}_{\mathrm{A}}$ receptor subunits at transcriptional and translational levels in brain area-specific manner, including reduction in $\delta$ subunit expression in the orbitofrontal cortex, cerebellum, hippocampus and amygdala. Changes in receptor composition might have important consequences for GABAergic neurotransmission, plasticity and behaviour including impairment in memory, anxiety, and executive and motor functions [201-203]. Furthermore, it was found that ethanol at concentrations of 20 to $100 \mathrm{mM}$ stimulates GABA-mediated uptake of chloride ions in isolated brain vesicles, and this effect can be blocked by the imidazobenzodiazepine Ro15-4513. Pre-treatment of rats with Ro154513 blocks the anticonflict activity of lower doses of ethanol, and behavioural intoxication observed with higher doses of ethanol. These effects of Ro15-4513 in antagonizing ethanolstimulated ${ }^{36} \mathrm{Cl}^{-}$uptake and behaviour can be completely blocked by benzodiazepine binding site antagonists, indicating that neuropharmacological actions of ethanol (20-100 mM) may be mediated via central GABA receptors [111]. Similarly, it was shown that $\left[{ }^{3} \mathrm{H}\right] \mathrm{Ro} 15-4513$ binding is inhibited only by those benzodiazepine-site ligands that reverse the behavioural alcohol antagonism of Ro15-4513 such as flumazenil and $\beta$-carboline-3-carboxylate ethyl ester ( $\beta$-CCE), but not by any classical benzodiazepine agonists. Additional experiments indicated that ethanol and Ro15-4513 occupy mutually exclusive binding sites. Since only Ro15-4513, but not flumazenil, can inhibit ethanol effects, and taking into account that Ro154513 differs from flumazenil by only a single group at the $\mathrm{C} 7$ position of the benzodiazepine ring, it is assumed that this group in Ro15-4513 might be the area that overlaps with the alcohol-binding site. Hence, it turns out that many of the behavioural effects of ethanol at relevant physiological concentrations are mediated via ethanol/Ro15-4513-sensitive GABA $_{A}$ receptors [112].

Wallner and co-workers [98] showed that differences in alcohol sensitivity toward $\beta$ subunits are determined by the extracellular $\mathrm{N}$-terminal part of the protein. By using point mutations, they discovered that the $\beta 3$ alcohol selectivity is determined by a single amino acid residue in the $\mathrm{N}$-terminus that differs between $\beta$ subunits ( $\beta 3$ Tyr66, $\beta 2$ Ala66, $\beta 1$ Ser66). The 33 Tyr66 residue is located in a region which in $\gamma$ subunits contributes to the imidazobenzodiazepine binding site at the classical $\alpha+\gamma 2$ - subunit interface. Furthermore, they proposed a model in which $\beta 3$ and $\delta$ containing $\mathrm{GABA}_{\mathrm{A}}$ receptors form a unique ethanol site at the $\alpha 4 / 6+\beta 3$ - subunit interface. As this site is homologous to the classical benzodiazepine 
binding site, it also has high affinity for a few selected benzodiazepine site ligands including alcohol antagonistic Ro15-4513 that bears large moiety at the C7 position of the benzodiazepine ring. They also suggested that large moieties at the C7-benzodiazepine ring compete with alcohol for its binding pocket at a $\alpha 4 / 6+\beta 3$ - ethanol/Ro15-4513 site, thus finally providing explanation for the competitive relationship between ethanol and imidazobenzodiazepine antagonists.

\section{Interactions of flavonoids with $\mathrm{GABA}_{\mathrm{A}}$ receptor}

Flavonoids represent a heterogeneous class of plant secondary metabolites. They exert a wide-range of health-promoting effects including antioxidative, anti-inflammatory, cardioprotective, anticarcinogenic, antidiabetic and neuroprotective activities [204-206]. Like many neuroactive drugs, they achieve their effects, at least in part, by modulating $\mathrm{GABA}_{\mathrm{A}}$ receptors [207,208]. Radioligand binding studies indicated that flavonoids exert a selective affinity for the benzodiazepine binding site at $\mathrm{GABA}_{\mathrm{A}}$ receptor complex, mostly acting as partial agonists [209]. Although it is initially thought that they act on classical, "high-affinity" benzodiazepine binding sites, many flavonoid actions are not inhibited by classical benzodiazepine antagonist flumazenil. For example, Hall et al. [210] have shown that 6methoxyflavanone and 6-methoxyflavone act as flumazenil-insensitive positive allosteric modulators of GABA responses at human recombinant $\alpha 1 \beta 2 \gamma 2 \mathrm{~L}$ and $\alpha 2 \beta 2 \gamma 2 \mathrm{~L} \mathrm{GABA}_{\mathrm{A}}$ receptors. Functional electrophysiological studies suggest that flavonoids act on $\mathrm{GABA}_{\mathrm{A}}$ receptors via two separate mechanisms: by acting on flumazenil-sensitive high-affinity site and an alternative site that may be the flumazenil-insensitive low-affinity benzodiazepine site [208]. However, as in aforementioned study 6-methoxyflavanone inhibited $\left[{ }^{3} \mathrm{H}\right]-$ flunitrazepam binding whilst remaining unaffected by flumazenil, this might suggest a novel allosteric binding site that is independent of both the high-affinity and low affinity benzodiazepine binding sites [210].

More importantly, some flavonoids may directly open certain subtypes of $\mathrm{GABA}_{\mathrm{A}}$ receptors in the absence of GABA [208]. Behavioural studies demonstrated anxiolytic effects of flavonoids in animal models. Some of the tested flavonoids (e.g. chrysin) have anxiolytic effects similar to diazepam, but not associated with myorelaxant, sedative or amnesic actions, suggesting that they could lead to improved therapeutic drugs in the treatment of anxiety [211,212]. However, in addition to positive modulation, flavonoids may also achieve negative 
effects on $\mathrm{GABA}_{\mathrm{A}}$ receptors [213,214]. Some flavonoids are positive neuromodulators when applied in the presence of low concentrations of GABA, but in the presence of high concentrations of GABA act as negative modulators [215]. A range of natural flavonoids act as negative modulators of receptors containing $\rho$-subunits.

Recently, it was found that quercetin and its glycosides inhibit GABA-induced inward current at recombinant $\mathrm{GABA}_{\mathrm{C}}$ receptors. These inhibitory effects of quercetin and quercetinglycosides on GABA-induced inward current were noncompetitive and membrane voltageinsensitive, indicating that quercetin and its glycosides regulate $G_{A B A}$ receptor channel activity through interaction with a different site from that of GABA [216]. This study also provides evidence that the number of carbohydrate attached to quercetin might play an important role in the regulation of $\mathrm{GABA}_{\mathrm{C}}$ receptor channel activity. On the contrary, 6methoxyflavanone and 6-methoxyflavone were inactive as modulators at human recombinant receptors containing $\rho 1$ subunits [210].

Interestingly, menthol, a naturally occurring compound in the essential oil of mint leaves, also act as a positive allosteric modulator of recombinant $\mathrm{GABA}_{\mathrm{A}}$ receptors. In particular, menthol $(150-750 \mu \mathrm{M})$ produced a concentration-dependent prolongation of spontaneous $\mathrm{GABA}_{\mathrm{A}}$ receptor-mediated inhibitory postsynaptic currents in the periaqueductal grey (PAG) neurons, although menthol actions were unaffected by the benzodiazepine antagonist flumazenil. Menthol also enhanced a tonic current, which was sensitive to the $\mathrm{GABA}_{\mathrm{A}}$ receptor antagonists picrotoxin and bicuculline, but unaffected by gabazine and $\mathrm{GABA}_{\mathrm{C}}$ receptor antagonist (1,2,5,6-tetrahydropyridine-4-yl)-methyl-phosphonic acid (TPMPA). In addition, menthol potentiated currents induced by the extrasynaptic GABA receptor agonist THIP, altogether indicating that menthol positively modulates both synaptic and extrasynaptic populations of $\mathrm{GABA}_{\mathrm{A}}$ receptors in native PAG neurons [217].

\section{GABAC receptors}

$\mathrm{GABA}_{\mathrm{C}}$ receptors are considered as a specific subtype of $\mathrm{GABA}_{\mathrm{A}}$ receptors due to their structural homology, although they differ from $\mathrm{GABA}_{\mathrm{A}}$ receptors by biochemical, pharmacological and physiological properties [218-220]. They are predominantly expressed in the retina where play a unique functional role in retinal signal processing, but are also expressed throughout brain and in periphery [221,222]. GABAC receptors are involved in numerous processes across the CNS, including vision, olfactory senses, sleep, memory and cognitive functions, hormone secretion and pain perception, with promising potential for the 
treatment of myopia, sleep disorders, memory and learning enhancement, and fear and anxiety-related disorders [222,223]. Although understanding of the role of GABA $\mathrm{C}$ receptors and processes triggered by ligand-receptor interactions in neurons are still limited because of the lack of adequate pharmacological tools, some progress has been made following synthesis and pharmacological evaluation of the selective fluorescent and biotinylated probes for $\rho_{1}$ $\mathrm{GABA}_{\mathrm{C}}$ receptors that hopefully will bring new knowledge regarding the binding site and $\mathrm{GABA}_{\mathrm{C}}$ receptors flexibility, and be useful tools for localizing, visualizing, and studying the physiopathological processes of GABAC receptors [224].

In mammals, there are three isoforms of $\rho$ subunits ( $\rho 1-\rho 3)$ that form homooligomeric (formed by $\rho 1, \rho 2$ or $\rho 3$ isoform) or pseudoheteromeric (made up of a combination of $\rho 1$ and $\rho 2$ isoforms or $\rho_{2}$ and $\rho_{3}$ isoforms) GABA receptor pentamers [220,224]. In humans, only two isoforms are expressed: $\rho 1$ and $\rho 2$.

$\mathrm{GABA}_{\mathrm{C}}$ receptors are sensitive neither to bicuculline (characteristic ligand of $\mathrm{GABA}_{\mathrm{A}}$ receptors) nor to baclofen (characteristic ligand of $\mathrm{GABA}$ B receptors) [222,225]. They are more sensitive to $\mathrm{GABA}$ than $\mathrm{GABA}_{\mathrm{A}}$ receptors, and at least three GABA molecules are required to activate the $\mathrm{GABA}_{C}$ receptor [222]. When activated, they have a smaller chloride conductance, longer channel opening time and desensitize less readily in the presence of GABA then $\mathrm{GABA}_{\mathrm{A}}$ receptors [218]. Benzodiazepines and barbiturates do not modulate $\mathrm{GABA}_{C}$ receptors [218]. Neuroactive steroids may modulate GABA-induced current at $\mathrm{GABA}_{\mathrm{C}}$ receptors, in particular at $\rho 1$ receptor channels, in both positive and negative manner, although the modulation occurs with relatively high concentrations of neuroactive steroids and is more prominent in the presence of low concentrations of GABA [226]. Characteristic agonists of $\mathrm{GABA}_{\mathrm{C}}$ receptors are cis enantiomer of 4-aminocrotonic acid (CACA) and (+)cis2-aminomethylcyclopropane carboxylic acid ((+)-CAMP) [218]. Furthermore, GABAC receptors are much less sensitive to $\mathrm{GABA}_{\mathrm{A}}$ receptor antagonist gabazine, but can be selectively antagonized by (1,2,5,6-tetrahydropyridine-4-yl)-methyl-phosphinic acid (TPMPA), 3-aminopropyl(methyl) phosphinic acid (3-APMPA), and 3aminopropylphosphonic acid (3-APA), indicating that agonist/antagonist binding pockets of $\mathrm{GABA}_{\mathrm{A}}$ and $\mathrm{GABA}_{\mathrm{C}}$ receptors are not the same [220,227,228]. Compound imidazole-4-acetic acid exhibits a $\rho$ subunit-dependent pharmacological profile: at $\rho 1$ and $\rho 3$ receptors acts as a potent antagonist, while at $\rho 2$ receptors as a potent partial agonist [222].

$\mathrm{N}$-terminal half of the $\rho$ subunits has been shown to mediate formation of homo- and heterooligomeric $\mathrm{GABA}_{\mathrm{C}}$ receptors, and specific sequence within the N-terminus of the $\rho 1$ subunit involved in the assembly process has been determined [229]. Furthermore, several 
key structural elements that determine specific pharmacological response of $\mathrm{GABA}_{\mathrm{C}}$ receptors have been found [228]. Namely, mutational studies, including those directed toward $\mathrm{N}$-terminal domain and transmembrane domain TM4, have revealed residues that change sensitivity to agonists or make GABAC complex inactive, and contribute to the binding pocket determining properties of GABA binding [221,230,231]. Thus, Tyr102 at $\rho 1$ subunit was identified as part of GABA binding domain, and probably the important residue for coupling agonist binding to channel opening [232]. Barbiturate sensitivity was imparted by mutation of Trp328 at $\rho 1$ subunit, located within the transmembrane domain TM3. It also seems that this residue plays an important role in agonist-dependent activation, suggesting a functional interconnection between the GABA and pentobarbital activation domains [233]. GABAC receptors that contain $\rho 2$ subunit exhibit decreased sensitivity to picrotoxin [234]. On $\rho 1$ receptor it is shown that the mechanism of picrotoxin effects is compatible with an allosteric inhibition and receptor activation was a prerequisite for antagonism [235]. Difference in picrotoxin sensitivity of $\rho 1$ and $\rho 2$ homo-oligomers is determined by a single residue. Interestingly, it was found that this amino acid in the putative channel domain (TM2) of GABA $\rho 1$ receptors influences picrotoxin sensitivity, and also meditates agonist binding by an allosteric mechanism [236].

\section{GABAв receptors}

Metabotropic $\mathrm{GABA}_{\mathrm{B}}$ receptors are G-protein coupled receptors that mediate slow and prolonged inhibitory neurotransmission in the brain [237]. They are widely expressed and distributed in the CNS, although $\mathrm{GABA}_{\mathrm{A}}$ sites generally outnumber $\mathrm{GABA}_{\mathrm{B}}$ sites [238]. $\mathrm{GABA}_{\mathrm{B}}$ receptors differ from $\mathrm{GABA}_{\mathrm{A}}$ receptors by their structural and functional properties, but also exhibit numerous pharmacological effects, including central muscle relaxation, epileptogenesis, suppression of drug craving, antinociception, cognitive impairment and inhibition of hormone release [12,239].

$\mathrm{GABA}_{\mathrm{B}}$ receptors can be located presynaptically and postsynaptically. Stimulation of presynaptic $\mathrm{GABA}_{\mathrm{B}}$ receptors decreases conductance of calcium ions via voltage-gated calcium channels. Consequently, activation of presynaptic $\mathrm{GABA}_{B}$ autoreceptors induces inhibition of GABA release, while presynaptic $\mathrm{GABA}_{\mathrm{B}}$ heteroreceptors suppress release of other neurotransmitters and bioactive peptides. Depending on whether synaptic terminal releases an inhibitory or excitatory neurotransmitter, presynaptic $\mathrm{GABA}_{\mathrm{B}}$ receptors will facilitate or suppress neuronal excitability thus playing important role in tuning various 
synapses $[12,240,241]$. On the other hand, postsynaptic $\mathrm{GABA}_{\mathrm{B}}$ receptors are coupled via Gproteins to inwardly rectifying potassium channels and underlie slow inhibitory postsynaptic currents. Postsynaptic $\mathrm{GABA}_{\mathrm{B}}$ receptors stimulate efflux of potassium ions that hyperpolarizes neuronal membrane and shunts excitatory currents. As presynaptic and postsynaptic $\mathrm{GABA}_{\mathrm{B}}$ receptors are dominantly located at extrasynaptic sites, their activation requires patterns of presynaptic activity that ends in simultaneous GABA spillover from neighbouring synapses and elevations of ambient GABA, as it occurs during epileptic seizures. Furthermore, the association of $\mathrm{GABA}_{\mathrm{B}}$ receptors with glutamatergic synapses suggests their important role in the modulation of glutamatergic neurotransmission [240,242,243].

The $\mathrm{GABA}_{\mathrm{B}}$ receptor was the first heteromeric G-protein coupled receptor identified. It functions as an obligatory heterodimer assembly: both $\mathrm{GABA}_{\mathrm{B} 1}$ and $\mathrm{GABA}_{\mathrm{B} 2}$ subunits are necessary to form a functional $\mathrm{GABA}_{\mathrm{B}}$ receptor, and neither of these subunits is functional on its own [244] (Kaupmann et al. 1998). Soon after the cloning of both subunits, it was demonstrated that $\mathrm{GABA}_{\mathrm{B} 2}$ is required for $\mathrm{GABA}_{\mathrm{B} 1}$ to reach the cell surface by masking an endoplasmic reticulum retention signal of $\mathrm{GABA}_{\mathrm{B} 1}$ [245]. However, $\mathrm{GABA}_{\mathrm{B} 2}$ is not only required for the correct trafficking of $\mathrm{GABA}_{\mathrm{B} 1}$, but also for the proper functioning of the receptor. In particular, $\mathrm{GABA}_{\mathrm{B} 1}$ is involved in ligand recognition via its $\mathrm{N}$-terminal extracellular domain and it binds GABA [246]. Although GABA ${ }_{\mathrm{B} 2}$ subunit does not constitute a binding site for any natural $\mathrm{GABA}_{\mathrm{B}}$ ligand [247], it enhances agonist affinity [248], and is required for receptor activation. In addition, $\mathrm{GABA}_{\mathrm{B} 2}$ subunit is responsible for G-protein coupling [249].

There are two physiologically significant isoforms of $\mathrm{GABA}_{\mathrm{B} 1}$ subunit, $\mathrm{GABA}_{\mathrm{B} 1 \mathrm{a}}$ and $\mathrm{GABA}_{\mathrm{B} 1 \mathrm{~b}}$ that differ in N-terminal region. Expression of these two subunits is developmentally regulated at the transcription level. They are transcribed from the same gene after activation of alternative promoters [250]. Accordingly, there are two major subtypes of $\mathrm{GABA}_{\mathrm{B}}$ receptor, one formed from $\mathrm{GABA}_{\mathrm{B} 2}$ and $\mathrm{GABA}_{\mathrm{B} 1 \mathrm{a}}$ subunits, and the other formed from $\mathrm{GABA}_{\mathrm{B} 2}$ and $\mathrm{GABA}_{\mathrm{B} 1 \mathrm{~b}}$ subunits [240].

$\mathrm{GABA}_{\mathrm{B} 1}$ and $\mathrm{GABA}_{\mathrm{B} 2}$ subunits are structurally homologous and both possess two main domains: a heptahelical membrane domain that is responsible for recognition and activation of G-proteins (HD domain), and a large extracellular "Venus flytrap" domain (VFT domain) involved in ligand binding. Both domains oscillate between different conformational states, and these allosteric transitions are essential for receptor function and offer numerous possibilities for the allosteric regulation of receptor activity. GABA and other agonists bind 
exclusively at the VFT domain of the $\mathrm{GABA}_{\mathrm{B} 1}$ subunit, but VFT domain of the GABA 2 subunit is necessary for the activation of whole receptor. On the other hand, GABA $\mathrm{B}_{2} \mathrm{HD}$ contains molecular determinants required for G-protein coupling, and by trans-activation mechanism, binding of GABA at VFT domain of GABAB1 subunit lead to activation of $\mathrm{HD}$ domain of $\mathrm{GABA}_{\mathrm{B} 2}$ subunit [251-253]. However, the HD of $\mathrm{GABA}_{\mathrm{B} 1}$ improves coupling efficacy. Conversely, although $\mathrm{GABA}_{\mathrm{B} 1}$ extracellular domain is sufficient to bind $\mathrm{GABA}_{\mathrm{B}}$ ligands, the extracellular domain of $\mathrm{GABA}_{\mathrm{B} 2}$ increases the agonist affinity on $\mathrm{GABA}_{\mathrm{B} 1}$, and is necessary for agonist activation of the receptor. Altogether, this indicates that multiple allosteric interactions between the two subunits are required for wild-type functioning of the $\mathrm{GABA}_{\mathrm{B}}$ receptor [251].

Geng et al. [254] presented the crystal structures of heterodimeric $\mathrm{GABA}_{\mathrm{B}}$ complex consisting of extracellular VFT domains of $\mathrm{GABA}_{\mathrm{B} 1}$ and $\mathrm{GABA}_{\mathrm{B} 2}$ subunits in the apo, agonist-bound and antagonist-bound forms. The apo and antagonist-bound structures represent the resting state of the receptor; while the agonist-bound complex corresponds to the active state. They found that both subunits adopt an open conformation at rest, but only $\mathrm{GABA}_{\mathrm{B} 1}$ VFT closes on agonist-induced receptor activation. Furthermore, they revealed a unique activation mechanism for $\mathrm{GABA}_{\mathrm{B}}$ receptor that involves the formation of a novel heterodimer interface between subunits.

$\mathrm{GABA}_{\mathrm{B}}$ receptors are not modulated by benzodiazepines, barbiturates, or steroids, and are not sensitive to bicuculline [218,225]. Characteristic agonists of $\mathrm{GABA}_{\mathrm{B}}$ receptors are baclofen, a lipophilic derivative of GABA, and 3-aminopropylphosponous acid (3-APPA; CGP27492), while saclofen, phaclofen and 2-hydroxysaclofen act as antagonists of GABA receptors [12]. Baclofen was introduced to the market in 1972 and is used to treat spasticity and skeletal muscle rigidity in patients with spinal cord injury, multiple sclerosis, amyotrophic lateral sclerosis, and cerebral palsy. However, although $\mathrm{GABA}_{B}$ agonists showed promising therapeutic effects in a whole range of other indications, they exhibit numerous side effects, including sedation, tolerance, and muscle relaxation $[237,256]$.

\section{Conclusions}

$\mathrm{GABA}_{\mathrm{A}}$ receptors mediate most of the fast synaptic inhibition in the mammalian brain and are targeted by many clinically important drugs. They are subject to modulation at a variety of allosteric sites, with pharmacology dependent on receptor subunit combination. In addition to GABA, naturally occurring steroids can potently and specifically enhance $\mathrm{GABA}_{\mathrm{A}}$ receptor function in a direct manner, and consequently exert anxiolytic, analgesic, 
anticonvulsant, sedative, hypnotic and anesthetic properties. $\mathrm{GABA}_{\mathrm{A}}$ receptors are thus important for function and plasticity of the CNS. Analysis of the specific roles of $G A B A_{A} R$ subtypes reveals their involvement in the pathophysiology of major CNS disorders, and opens novel perspectives for therapeutic intervention. Further pharmacological studies will contribute to more complete understanding of numerous interactions between various ligands and their binding sites on GABA receptors that might improve current pharmacological approach in treating various diseases.

\section{Acknowledgments}

This work was supported by Croatian Ministry of Science, Education and Sports to MJJ and JV.

\section{References}

[1] Somogyi P, Klausberger T. Defined types of cortical interneurone structure space and spike timing in the hippocampus. 2005; 562(Pt 1): 9-26.

[2] Buzsáki G, Kaila K, Raichle M. Inhibition and brain work. Neuron. 2007; 56: 771-83.

[3] Ferando I, Mody I. Interneuronal $\mathrm{GABA}_{\mathrm{A}}$ receptors inside and outside of synapses. Curr Opin Neurobiol 2014; 26: 57-63.

[4] Rudolph U, Knoflach F. Beyond classical benzodiazepines: novel therapeutic potential of $\mathrm{GABA}_{A}$ receptor subtypes. Nat Rev Drug Discov 2011; 10(9): 685-97.

[5] Sigel E, Steinmann ME. Structure, function, and modulation of GABA(A) receptors. J Biol Chem 2012; 287(48): 40224-31.

[6] Korpi ER, Grunder G, Lüddens H. Drug interactions at GABA(A) receptors. Prog Neurobiol 2002; 67: 113-59.

[7] Tsang SY, Xue H. Development of effective therapeutics targeting the GABAA receptor: naturally occurring alternatives. Curr Pharm Des 2004; 10(9): 1035-44.

[8] Licata SC, Rowlett JK.) Abuse and dependence liability of benzodiazepine-type drugs: GABA(A) receptor modulation and beyond. Pharmacol Biochem Behav 2008; 90(1): 74-89. 
[9] Vlainić J, Peričić D. Effects of acute and repeated zolpidem treatment on pentylenetetrazole-induced seizure threshold and on locomotor activity: comparison with diazepam. Neuropharmacology 2009; 56(8): 1124-30.

[10] Vinkers CH, Olivier B. Mechanisms underlying tolerance after long-term benzodiazepine use: a future for subtype-selective $\mathrm{GABA}_{\mathrm{A}}$ receptor modulators? Advances in Pharmacological Sciences 2012: 416864.

[11] Jazvinšćak Jembrek M, Vlainić J, Šuran J. Zolpidem withdrawal induced uncoupling of GABAA receptors in vitro associated with altered $\mathrm{GABA}_{\mathrm{A}}$ receptor subunit mRNA expression. Acta Neurobiol Exp 2015; 75: 160-71.

[12] Bowery NG, Bettler B, Froestl W, Gallagher JP, Marshall F, Raiteri M, Bonner TI, Enna SJ. International Union of Pharmacology. XXXIII. Mammalian $\gamma$-aminobutyric acid (B) receptors: structure and function. Pharmacol Rev 2002; 54(2): 247-64.

[13] Miller PS, Smart TG. Binding, activation and modulation of Cys-loop receptors. Trends Pharmacol Sci 2010; 31(4): 161-74.

[14] Olsen RW, Sieghart W. International Union of Pharmacology. LXX. Subtypes of gamma-aminobutyric acid (A) receptors: classification on the basis of subunit composition, pharmacology, and function. Update Pharmacol Rev 2008; 60(3): 243-60.

[15] Barnard EA, Skolnick P, Olsen RW, et al. International union of pharmacology: XV. Subtypes of $\gamma$-Aminobutyric $\operatorname{acid}_{\mathrm{A}}$ receptors: classification on the basis of subunit structure and receptor function. Pharmacol Rev 2008; 50: 291-313.

[16] Sieghart W, Fuchs K, Tretter V, et al. Structure and subunit composition of GABA receptors. Neurochem Int 1999; 34: 379-85.

[17] Uusi-Oukari M, Korpi ER. Regulation of $\mathrm{GABA}_{\mathrm{A}}$ receptor subunit expression by pharmacological agents. Pharmacol Rev 2010; 62(1): 97-135.

[18] Hörtnagl H, Tasan RO, Wieselthaler A, Kirchmair E, Sieghart W, Sperk G. Patterns of mRNA and protein expression for $12 \mathrm{GABA}_{\mathrm{A}}$ receptor subunits in the mouse brain. Neuroscience 2013; 236: 345-72. 
[19] Laurie DJ, Seeburg PH, Wisden W. The distribution of $13 \mathrm{GABA}_{\mathrm{A}}$ receptor subunit mRNAs in the rat brain. II. Olfactory bulb and cerebellum. J Neurosci 1992; 12(3): 1063-76.

[20] Wisden W, Laurie DJ, Monyer H, Seeburg PH. The distribution of $13 \mathrm{GABA}_{\mathrm{A}}$ receptor subunit mRNAs in the rat brain. I. Telencephalon, diencephalon, mesencephalon. J. Neurosci 1992; 12(3): 1040-62.

[21] Zhang D, Pan ZH, Awobuluyi M, Lipton SA. Structure and function of GABA(C) receptors: a comparison of native versus recombinant receptors. Trends Pharmacol Sci 2001; 22(3): 121-32.

[22] Glykys J, Mann EO, Mody I. Which GABA(A) receptor subunits are necessary for tonic inhibition in the hippocampus? J Neurosci 2008; 28(6): 1421-6.

[23] Fritschy JM, Panzanelli P. GABAA receptors and plasticity of inhibitory neurotransmission in the central nervous system. Eur J Neurosci 2014; 39(11): 1845-6.5

[24] Olsen RW, Sieghart W. GABA $A_{A}$ receptors: subtypes provide diversity of function and pharmacology. Neuropharmacology 2009; 56: 141-8.

[25] Chen $\mathrm{ZW}$, Olsen RW. GABAA receptor associated proteins: a key factor regulating $\mathrm{GABA}_{\mathrm{A}}$ receptor function. J Neurochem 2007; 100(2): 279-94.

[26] Darlison MG, Pahal I, Thode C. Consequences of the evolution of the GABA(A) receptor gene family. Cell Mol Neurobiol 2005; 25(3-4): 607-24.

[27] Daniel C, Ohman M. RNA editing and its impact on $\mathrm{GABA}_{\mathrm{A}}$ receptor function. Biochem Soc Trans 2009; 37(Pt 6): 1399-403.

[28] Jin P, Zhang J, Rowe-Teeter C, Yang J, Stuve LL, Fu GK. Cloning and characterization of a $\mathrm{GABA}_{\mathrm{A}}$ receptor $\gamma 2$ subunit variant. J Biol Chem 2004; 279: 1408-14.

[29] Dredge BK, Darnell RB. Nova regulates GABA(A) receptor $\gamma 2$ alternative splicing via a distal downstream UCAU-rich intronic splicing enhancer. Mol Cell Biol 2003; 23(13): 4687700. 
[30] Tretter V, Ehya N, Fuchs K, Sieghart W. Stoichiometry and assembly of a recombinant $\mathrm{GABA}_{\mathrm{A}}$ receptor subtype. J Neurosci 1997; 17: 2728-37.

[31] Gunn BG, Cunningham L, Mitchell SG, Swinny JD, Lambert JJ, Belelli D. GABA A receptor-acting neurosteroids: a role in the development and regulation of the stress response. Front Neuroendocrinol 2015; 36: 28-48.

[32] Baumann SW, Baur R, Sigel E. Forced subunit assembly in $\alpha 1 \beta 2 \gamma 2 \mathrm{GABA}_{\mathrm{A}}$ receptors. Insight into the absolute arrengement. J Biol Chem 2002; 277: 46020-5.

[33] Pöltl A, Hauer B, Fuchs K, Tretter V, Sieghart W. Subunit composition and quantitative importance of $\operatorname{GABA}(\mathrm{A})$ receptor subtypes in the cerebellum of mouse and rat. J Neurochem 2003; 87(6): 1444-55

[34] Sieghart W, Sperk G. Subunit composition, distribution and function of GABA(A) receptor subtypes. Curr Top Med Chem 2002; 2(8): 795-816.

[35] Minier F, Sigel E. Positioning of the $\alpha$-subunit isoforms confers a functional signature to $\gamma$-aminobutyric acid type A receptors. Proc Natl Acad Sci USA 2004; 101(20): 7769-74.

[36] Zezula J, Slany A, Sieghart W. Interaction of allosteric ligands with GABAA receptors containing one, two, or three different subunits. Eur J Pharmacol 1996; 301: 207-14.

[37] Farrant M, Nusser Z. Variations on an inhibitory theme: phasic and tonic activation of $\mathrm{GABA}_{A}$ receptors. Nat Rev Neurosci 2005; 6: 215-29.

[38] Belelli D, Harrison NL, Maguire J, Macdonald RL, Walker MC, Cope DW. Extrasynaptic $\mathrm{GABA}_{\mathrm{A}}$ receptors: form, pharmacology, and function. J Neurosci 2009; 29: $12757-63$.

[39] Brickley SG, Mody I. Extrasynaptic GABA(A) receptors: their function in the CNS and implications for disease. Neuron 2012; 73(1): 23-34.

[40] Carver CM, Reddy DS. Neurosteroid interactions with synaptic and extrasynaptic $\mathrm{GABA}(\mathrm{A})$ receptors: regulation of subunit plasticity, phasic and tonic inhibition, and neuronal network excitability. Psychopharmacology (Berl) 2013; 230(2): 151-88. 
[41] Whissell PD, Lecker I, Wang DS, Yu J, Orser BA. Altered expression of $\delta G_{A B A}$ receptors in health and disease. Neuropharmacology 2015; 88: 24-35.

[42] Clarkson AN, Huang BS, Macisaac SE, Mody I, Carmichael ST. Reducing excessive GABA-mediated tonic inhibition promotes functional recovery after stroke. Nature 2010; 468(7321): 305-9.

[43] Bonin RP, Labrakakis C, Eng DG, Whissell PD, De Koninck Y, Orser BA. Pharmacological enhancement of $\delta$-subunit-containing $\operatorname{GABA}(\mathrm{A})$ receptors that generate a tonic inhibitory conductance in spinal neurons attenuates acute nociception in mice. Pain 2011; 152(6): 1317-26.

[44] Cushman JD, Moore MD, Olsen RW, Fanselow MS. The role of the $\delta$ GABA(A) receptor in ovarian cycle-linked changes in hippocampus-dependent learning and memory. Neurochem Res 2014; 39(6): 1140-6.

[45] Maguire JL, Stell BM, Rafizadeh M, Mody I. Ovarian cycle-linked changes in GABA(A) receptors mediating tonic inhibition alter seizure susceptibility and anxiety. Nat Neurosci 2005; 8(6):797-804.

[46] Maguire J, Mody I. GABA(A)R plasticity during pregnancy: relevance to postpartum depression. Neuron 2008; 59(2): 207-13.

[47] Maldonado-Avilés JG, Curley AA, et al. Altered markers of tonic inhibition in the dorsolateral prefrontal cortex of subjects with schizophrenia. Am J Psychiatry 2009; 166(4): 450-9.

[48] Genud R, Merenlender A, Gispan-Herman I, Maayan R, Weizman A, Yadid G. DHEA lessens depressive-like behavior via GABA-ergic modulation of the mesolimbic system. Neuropsychopharmacol 2009; 34(3): 577-84.

[49] Belelli D, Lambert JJ. Neurosteroids: endogenous regulators of the GAB $\mathrm{AA}_{\mathrm{A}}$ receptor. Nat Rev Neurosci 2005; 6: 565-75.

[50] Barbaccia ML, Serra M, Purdy RH, Biggio G. Stress and neuroactive steroids. Int Rev Neurobiol 2001; 46: 243-72. 
[51] Stoffel-Wagner B (2001) Neurosteroid metabolism in the human brain. Eur J Endocrinol. 145(6):669-679.

[52] Morrow AL, Biggio G, Serra M, et al. The role of neuroactive steroids in ethanol/stress interactions: proceedings of symposium VII at the Volterra conference on alcohol and stress. Alcohol 2009; 43(7): 521-30.

[53] Lambert JJ, Belelli D, Peden DR, Vardy AW, Peters JA. Neurosteroid modulation of $\mathrm{GABA}_{A}$ receptors. Prog Neurobiol 2003; 71: 67-80.

[54] Comenencia-Ortiz E, Moss SJ, Davies PA. Phosphorylation of GABAA receptors influences receptor trafficking and neurosteroid actions. Psychopharmacology (Berl) 2014; 231(17): 3453-65.

[55] Sigel E, Baur R, Rácz I, et al. The major central endocannabinoid directly acts at GABA(A) receptors. Proc Natl Acad Sci USA 2011; 108(44): 18150-5.

[56] Baur R, Kielar M, Richter L, Ernst M, Ecker GF, Sigel E. Molecular analysis of the site for 2-arachidonylglycerol (2-AG) on the $\beta 2$ subunit of GABAA receptors. J Neurochem 2013; 126(1): 29-36.

[57] Mehta AK, Ticku MK. An update on GABAA receptors. Brain Res Rev 1999; 29: 196217.

[58] Ernst M, Bruckner S, Boresch S, Sieghart W. Comparative models of GABAA receptor extracellular and transmembrane domains: important insights in pharmacology and function. Mol Pharmacol 2005; 68(5): 1291-300.

[59] Sieghart W. Structure and pharmacology of GABAA receptor subtypes. Pharmacol Rev 1995; 47(2): 181-234.

[60] Rho JM, Donevan SD, Rogawski MA. Direct activation of $\mathrm{GABA}_{\mathrm{A}}$ receptors by barbiturates in cultured rat hippocampal neurons. J Physiol 1996; 497: 509-22.

[61] Rosen A, Bali M, Horenstein J, Akabas MH. Channel opening by anesthetics and GABA induces similar changes in the $\mathrm{GABA}_{\mathrm{A}}$ receptor M2 segment. Biophys J 2007; 92(9): 3130-9. 
[62] Bianchi MT, Botzolakis EJ, Lagrange AH, Macdonald RL. Benzodiazepine modulation of $\mathrm{GABA}(\mathrm{A})$ receptor opening frequency depends on activation context: a patch clamp and simulation study. Epilepsy Res 2009; 85(2-3): 212-20.

[63] Garcia PS, Kolesky SE, Jenkins A. General anesthetic actions on GABA(A) receptors. Curr Neuropharmacol 2010; 8(1):2-9.

[64] Wagner DA, Czajkowski C. Structure and dynamics of the GABA binding pocket: a narrowing cleft that constricts during activation. J Neurosci 2001; 21: 67-74.

[65] Berezhnoy D, Baur R, Gonthier A, Foucaud B, Goeldner M, Sigel E. Conformational changes at benzodiazepine binding sites of $\mathrm{GABA}_{\mathrm{A}}$ receptors detected with a novel technique. J Neurochem 2005; 92: 859-66.

[66] Sieghart W. Allosteric modulation of $\mathrm{GABA}_{\mathrm{A}}$ receptors via multiple drug-binding sites. Adv Pharmacol 2015; 72: 53-96.

[67] Nikolaus S, Antke C, Beu M, Müller HW. Cortical GABA, striatal dopamine and midbrain serotonin as the key players in compulsive and anxiety disorders - results from in vivo imaging studies. Rev Neurosci 2010; 21(2): 119-39.

[68] Ravindran LN, Stein MB. The pharmacologic treatment of anxiety disorders: a review of progress. J Clin Psychiatry 2010; 71(7): 839-54.

[69] Rudolph U, Möhler H. GABA A receptor subtypes: Therapeutic potential in Down syndrome, affective disorders, schizophrenia, and autism. Annu Rev Pharmacol Toxicol 2014; 54: 483-507.

[70] Zarnowska ED, Keist R, Rudolph U, Pearce RA. GABA A receptor $\alpha 5$ subunits contribute to $\mathrm{GABA}_{\mathrm{A}}$, slow synaptic inhibition in mouse hippocampus. J Neurophysiol 2009; 101(3): 1179-91.

[71] Babateen O, Jin Z, Bhandage A, et al. Etomidate, propofol and diazepam potentiate GABA-evoked $\mathrm{GABA}_{\mathrm{A}}$ currents in a cell line derived from human glioblastoma. Eur $\mathrm{J}$ Pharmacol 2015; 748: 101-7. 
[72] Członkowska AI, Sienkiewicz-Jarosz H, Siemiatkowski M, Bidziński A, Płaźnik A. The effects of neurosteroids on rat behavior and ${ }^{3} \mathrm{H}$-muscimol binding in the brain. Pharmacol Biochem Behav 1999; 63(4): 639-46.

[73] Ran R, Gu J, Fu J, et al. The role of the GABA-A receptor of the adjacent intact dorsal root ganglion neurons in rats with neuropathic pain. Acta Neurobiol Exp (Wars) 2014; 74(4): 405-14.

[74] Johnston GA. Muscimol as an ionotropic GABA receptor agonist. Neurochem Res 2014; 39(10): 1942-7.

[75] Mortensen M, Ebert B, Wafford K, Smart TG. Distinct activities of GABA agonists at synaptic- and extrasynaptic-type $\mathrm{GABA}_{\mathrm{A}}$ receptors. J Physiol 2010; 588(Pt 8): 1251-68.

[76] Chandra D, Halonen LM, Linden AM, Procaccini C, et al. Prototypic GABA(A) receptor agonist muscimol acts preferentially through forebrain high-affinity binding sites. Neuropsychopharmacology 2010; 35(4): 999-1007.

[77] Verdurand M, Fillman SG, Shannon Weickert C, Zavitsanou K. Increases in $\left[{ }^{3} \mathrm{H}\right]$ muscimol and $\left[{ }^{3} \mathrm{H}\right]$ flumazenil binding in the dorsolateral prefrontal cortex in schizophrenia are linked to $\alpha 4$ and $\gamma 2 \mathrm{~S}$ mRNA levels respectively. PLoS ONE 2013; 8(1): e52724.

[78] Lee BY, Ban JY, Seong YH. Chronic stimulation of $\mathrm{GABA}_{\mathrm{A}}$ receptor with muscimol reduces amyloid $\beta$ protein (25-35)-induced neurotoxicity in cultured rat cortical cells. Neurosci Res 2005; 52(4): 347-56.

[79] Willow M, Johnston GA. Enhancement of GABA binding by pentobarbitone. Neurosci Lett 1980; 18(3): 323-7.

[80] Viapiano MS, de Novara AM, de Plazas SF. Neurosteroid modulation of GABA binding sites in developing avian central nervous system. Neurochem Int 1998; 32(3): 291-8.

[81] Peričić D, Jazvinšćak M, Mirković K. [ $\left.{ }^{3} \mathrm{H}\right]$ Flunitrazepam binding to recombinant $\alpha_{1} \beta_{2} \gamma_{2} S$ $\mathrm{GABA}_{\mathrm{A}}$ receptors stably expressed in HEK 293 cells. Biomed Pharmacother 2001; 55(4): 221-8. 
[82] Atack JR, Ohashi Y, McKernan RM. Characterization of $\left[{ }^{35} \mathrm{~S}\right] \mathrm{t}-$ butylbicyclophosphorothionate $\left(\left[{ }^{35} \mathrm{~S}\right] \mathrm{TBPS}\right)$ binding to $\mathrm{GABA}_{\mathrm{A}}$ receptors in postmortem human brain. Br J Pharmacol 2007; 150(8): 1066-74.

[83] Akk G, Li P, Bracamontes J, Wang M, Steinbach JH. Pharmacology of structural changes at the $\mathrm{GABA}_{\mathrm{A}}$ receptor transmitter binding site. Br J Pharmacol 2011; 162(4): 84050 .

[84] Baur R, Sigel E. On high- and low-affinity agonist sites in GABAA receptors. J Neurochem 2003; 87(2): 325-32.

[85] Boileau AJ, Evers AR, Davis AF, Czajkowsky C. Mapping the agonist binding site of the $\mathrm{GABA}_{\mathrm{A}}$ receptor: Evidence for a $\beta$-strand. J Neurosci 1999; 19: 4847-54.

[86] Bergmann R, Kongsbak K, Sørensen PL, Sander T, Balle T. A Unified Model of the $\mathrm{GABA}_{\mathrm{A}}$ Receptor Comprising Agonist and Benzodiazepine Binding Sites. PLoS ONE 2013; 8(1): e52323.

[87] Laha KT, Tran PN. Multiple tyrosine residues at the GABA binding pocket influence surface expression and mediate kinetics of the $\mathrm{GABA}_{\mathrm{A}}$ receptor. J Neurochem 2013; 124(2): 200-9.

[88] Baumann SW, Baur R, Sigel E. Individual properties of the two functional agonist sites in GABA(A) receptors. J Neurosci 2003; 23(35): 11158-66.

[89] Karim N, Wellendorph P, Absalom N, et al. Low nanomolar GABA effects at extrasynaptic $\alpha 4 \beta 1 / \beta 3 \delta$ GABA(A) receptor subtypes indicate a different binding mode for GABA at these receptors. Biochem Pharmacol 2012; 84(4): 549-57.

[90] McKernan RM, Rosahl TW, Reynolds DS, et al. Sedative but not anxiolytic properties of benzodiazepines are mediated by the GABA(A) receptor $\alpha 1$ subtype. Nat Neurosci 2000; 3(6): 587-92.

[91] Crestani F, Löw K, Keist R, Mandelli M-J, Möhler H, Rudolph U. Molecular targets for the myorelaxant action of diazepam. Mol Pharmacol 2001; 59: 442-5. 
[92] Rudolph U, Crestani F, Möhler H. GABA(A) receptor subtypes: dissecting their pharmacological functions.Trends Pharmacol Sci 2001; 22(4): 188-94.

[93] Atack JR. The benzodiazepine binding site of GABA(A) receptors as a target for the development of novel anxiolytics. Expert Opin Investig Drugs 2005; 14(5): 601-18.

[94] Crestani F, Keist R, Fritschy JM, et al. Trace fear conditioning involves hippocampal $\alpha 5$ GABA(A) receptors. Proc Natl Acad Sci USA 2002; 99(13): 8980-5.

[95] Collinson N, Kuenzi FM, Jarolimek W, et al. Enhanced learning and memory and altered GABAergic synaptic transmission in mice lacking the $\alpha 5$ subunit of the $\mathrm{GABA}_{\mathrm{A}}$ receptor. $\mathrm{J}$ Neurosci 2002; 22(13): 5572-80.

[96] Wisden W, Herb A, Wieland H, Keinänen K, Lüddens H, Seeburg PH. Cloning, pharmacological characteristics and expression pattern of the rat $\mathrm{GAB}_{\mathrm{A}}$ receptor $\alpha 4$ subunit. FEBS Lett 1991; 289: 227-30.

[97] Wafford KA, Thompson SA, Thomas D, Sikela J, Wilcox AS, Whiting PJ. Functional characterization of human gamma-aminobutyric $\operatorname{acid}_{\mathrm{A}}$ receptors containing the $\alpha 4$ subunit. Mol Pharmacol 1996; 50: 670-8.

[98] Wallner M, Hanchar HJ, Olsen RW. Alcohol selectivity of $\beta 3$-containing GABA $_{A}$ receptors: evidence for a unique extracellular alcohol/imidazobenzodiazepine Ro15-4513 binding site at the $\alpha+\beta$ - subunit interface in $\alpha \beta 3 \delta$ GABAA $_{A}$ receptors. Neurochem Res 2014; 39(6): 1118-26.

[99] Hauser CA, Wetzel CH, Berning B, Gerner FM, Rupprecht R. Flunitrazepam has an inverse agonistic effect on recombinant $\alpha 6 \beta 2 \gamma 2-\mathrm{GABA}_{\mathrm{A}}$ receptors via a flunitrazepambinding site. J Biol Chem 1997; 272(18): 11723-7.

[100] Sigel E, Lüscher BP. A closer look at the high affinity benzodiazepine binding site on $\mathrm{GABA}_{\mathrm{A}}$ receptors. Curr Top Med Chem 2011; 11(2): 241-6.

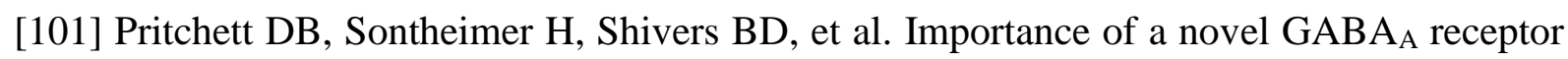
subunit for benzodiazepine pharmacology. Nature 1989; 338(6216): 582-5. 
[102] Hanson SM, Czajkowski C. Structural mechanisms underlying benzodiazepine modulation of the GABA(A) receptor. J Neurosci 2008; 28(13): 3490-9.

[103] Kucken AM, Wagner DA, Ward PR, Teissére JA, Boileau AJ, Czajkowski C. Identification of benzodiazepine binding site residues in the $\gamma 2$ subunit of the $\gamma$-aminobutyric $\operatorname{acid}_{\mathrm{A}}$ receptor. Mol Pharmacol 2000; 57: 932-9.

[104] Berezhnoy D, Nyfeler Y, Gonthier A, Schwob H, Goeldner M, Sigel E. On the benzodiazepine binding pocket in $\mathrm{GABA}_{\mathrm{A}}$ receptors. J Biol Chem 2004; 279: 3160-8.

[105] Tan KR, Baur R, Charon S, Goeldner M, Sigel E. Relative positioning of diazepam in the benzodiazepine-binding-pocket of GABA receptors. J Neurochem 2009; 111(5): 1264-73.

[106] Bentzen $\mathrm{BH}$, Grunnet M. Central and peripheral $\mathrm{GABA}_{\mathrm{A}}$ receptor regulation of the heart rate depends on the conscious state of the animal. Advances in pharmacological sciences $2011 ; 578273$.

[107] Richter L, de Graaf C, Sieghart W, et al. Diazepam-bound GABAA receptor models identify new benzodiazepine binding-site ligands. Nat Chem Biol 2012; 8(5): 455-64.

[108] Walters RJ, Hadley SH, Morris KD, Amin J. Benzodiazepines act on GABA $A_{A}$ receptors via two distinct and separable mechanisms. Nat Neurosci 2012; 3(12): 1274-81.

[109] Stevenson A, Wingrove PB, Whiting PJ, Wafford KA. beta-Carboline gammaaminobutyric acidA receptor inverse agonists modulate gamma-aminobutyric acid via the loreclezole binding site as well as the benzodiazepine site. Mol Pharmacol 1995; 48(6): 965-9.

[110] Baur R, Tan KR, Lüscher BP, Gonthier A, Goeldner M, Sigel E. Covalent modification of $\mathrm{GABA}_{\mathrm{A}}$ receptor isoforms by a diazepam analogue provides evidence for a novel benzodiazepine binding site that prevents modulation by these drugs. J Neurochem 2008; 106(6): 2353-63.

[111] Suzdak PD, Glowa JR, Crawley JN, Schwartz RD, Skolnick P, Paul SM. A selective imidazobenzodiazepine antagonist of ethanol in the rat. Science 1986; 234(4781): 1243-7. 
[112] Hanchar HJ, Chutsrinopkun P, Meera P, et al. Ethanol potently and competitively inhibits binding of the alcohol antagonist Ro15-4513 to $\alpha_{4 / 6} \beta_{3} \delta \mathrm{GABA}_{\mathrm{A}}$ receptors. Proc Natl Acad Sci USA 2006; 103(22): 8546-51.

[113] Ramerstorfer J, Furtmüller R, Sarto-Jackson I, Varagic Z, Sieghart W, Ernst M. The $\mathrm{GABA}_{\mathrm{A}}$ receptor $\alpha+\beta$ - interface: a novel target for subtype selective drugs. J Neurosci 2011; 31(3): 870-7.

[114] Spurny R, Ramerstorfer J, Price K, et al. Pentameric ligand-gated ion channel ELIC is activated by GABA and modulated by benzodiazepines. Proc Natl Acad Sci USA 2012; 109(44): E3028-34.

[115] Ashton H. The diagnosis and management of benzodiazepine dependence. Curr Opin Psychiatry 2005; 18(3): 249-55.

[116] Hood SD, Norman A, Hince DA, Melichar JK, Hulse GK. Benzodiazepine dependence and its treatment with low dose flumazenil. Br J Clin Pharmacol 2014; 77(2): 285-94.

[117] Janhsen K, Roser P, Hoffmann K. The problems of long-term treatment with benzodiazepines and related substances. Dtsch Arztebl Int 2015; 112(1-2): 1-7.

[118] Rundfeldt C, Löscher W. The pharmacology of imepitoin: the first partial benzodiazepine receptor agonist developed for the treatment of epilepsy. CNS Drugs 2014; 28(1): 29-43.

[119] Peričić D, Jazvinšćak Jembrek M, Švob Štrac D, Lazić J, Rajčan Špoljarić I. Enhancement of benzodiazepine binding sites following chronic treatment with flumazenil. Eur J Pharmacol 2005; 507(1-3): 7-13.

[120] Peričić D, Švob Štrac D, Jazvinšćak Jembrek M, Vlainić J. Allosteric uncoupling and up-regulation of benzodiazepine and GABA recognition sites following chronic diazepam treatment of HEK 293 cells stably transfected with $\alpha_{1} \beta_{2} \gamma_{2}$ s subunits of GABAA receptors. Naunyn Schmiedebergs Arch Pharmacol 2007; 375: 177-87.

[121] Jazvinšćak Jembrek M, Švob Štrac D, Vlainić J, Peričić D. The role of transcriptional and translational mechanisms in flumazenil-induced up-regulation of recombinant $\mathrm{GABA}_{\mathrm{A}}$ receptors. Neurosci Res 2008; 61: 234-41. 
[122] Švob Štrac D, Vlainić J, Jazvinšćak Jembrek M, Peričić D. Differential effects of diazepam treatment and withdrawal on recombinant $\mathrm{GABA}_{\mathrm{A}}$ receptor expression and functional coupling. Brain Res 2008; 1246: 29-40.

[123] Vlainić J, Jazvinšćak Jembrek M, Vlainić T, Švob Štrac D, Peričić D. Differential effects of short- and long-term zolipdem treatment on recombinant $\alpha 1 \beta 2 \gamma 2$ s subtype of $\mathrm{GABA}_{\mathrm{A}}$ receptors in vitro. Acta Pharmacol Sin 2012; 33: 1469-76.

[124] Vlainić J, Švob Štrac D, Jazvinšćak Jembrek M, Vlainić T, Peričić D. The effects of zolpidem treatment on $\mathrm{GABA}_{\mathrm{A}}$ receptors in cultured cerebellar granule cells: changes in functional coupling. Life Sci 2012; 90: 889-94.

[125] Peričić D, Mirković K, Jazvinšćak M, Besnard F. [ $\left.{ }^{3} \mathrm{H}\right]$ t-butylbicycloorthobenzoate binding to recombinant $\alpha_{1} \beta_{2} \gamma_{2 S} \mathrm{GABA}_{\mathrm{A}}$ receptor. Eur J Pharmacol 1998; 360(1): 99-104.

[126] Peričić D, Švob D, Jazvinšćak M, Mirković K. Anticonvulsive effect of swim stress in mice. Pharmacol Biochem Behav 2000; 66(4): 879-86.

[127] Walsh LA, Li M, Zhao TJ, Chiu TH, Rosenberg HC. Acute pentylenetetrazol injection reduces rat $\mathrm{GABA}_{\mathrm{A}}$ receptor $\mathrm{mRNA}$ levels and $\mathrm{GABA}$ stimulation of benzodiazepine binding with no effect on benzodiazepine binding site density. J Pharmacol Exp Ther 1999; 289(3): 1626-33.

[128] Kalueff AV. Mapping convulsants' binding to the $\mathrm{GABA}_{\mathrm{A}}$ receptor chloride ionophore: a proposed model for channel binding sites. Neurochem Int 2007; 50: 61-8.

[129] Im WB, Pregenzer JF. Interaction of $\mathrm{La}^{3+}$ with $\mathrm{GABA}_{\mathrm{A}}$ receptors in rat cerebrocortical membranes as detected with $\left[{ }^{35} \mathrm{~S}\right] t$-butylbicyclophosphorothionate binding. Eur J Pharmacol Mol Pharmacol Sect 1993; 245: 111-7.

[130] Lüddens H, Korpi ER. GABA antagonists differentiate between recombinant $\mathrm{GABA}_{\mathrm{A}} /$ benzodiazepine receptor subtypes. J Neurosci 1995; 15(10): 6957-62.

[131] Fodor L, Bíró T, Maksay G. Nanomolar allopregnanolone potentiates rat cerebellar $\mathrm{GABA}_{\mathrm{A}}$ receptors. Neurosci Lett 2005; 383: 127-30. 
[132] Othman NA, Gallacher M, Deeb TZ, Baptista-Hon DT, Perry DC, Hales TG. Influences on blockade by $t$-butylbicyclo-phosphoro-thionate of $\mathrm{GABA}_{\mathrm{A}}$ receptor spontaneous gating, agonist activation and desensitization. J Physiol 2012; 590(Pt 1): 163-78.

[133] Im WB, Blakeman DP. Correlation between $\gamma$-aminobutyric aci ${ }_{\mathrm{dA}}$ receptor ligandinduced changes in $t$-butylbicyclophosphoro $\left.{ }^{[35} \mathrm{S}\right]$ thionate binding and ${ }^{36} \mathrm{Cl}^{-}$uptake in rat cerebrocortical membranes. Mol Pharmacol 1991; 39: 394-8.

[134] Korpi ER, Lüddens H. Regional $\gamma$-aminobutyric acid sensitivity of $t$-butylbicyclo phosphoro $\left[{ }^{35} \mathrm{~S}\right]$ thionate binding depends on $\gamma$-aminobutyric $\operatorname{acid}_{\mathrm{A}}$ receptor $\alpha$ subunit. Mol Pharmacol 1993; 44: 87-92.

[135] Gurley D, Amin J, Ross PC, Weiss DS, White G. Point mutations in the M2 region of the $\alpha, \beta$, or $\gamma$ subunit of the $\mathrm{GABA}_{\mathrm{A}}$ channel that abolish block by picrotoxin. Rec Channels 1995;3: 13-20.

[136] Dillon GH, Im WB, Carter DB, McKinley DD. Enhancement by GABA of the association rate of picrotoxin and tert-butylbicyclophosphorothionate to the rat cloned $\alpha 1 \beta 2 \gamma 2$ $\mathrm{GABA}_{\mathrm{A}}$ receptor subtype. Br J Pharmacol 1995; 115(3): 539-45.

[137] Behrends JC. Modulation by bicuculline and penicillin of the block by t-butyl-bicyclophosphorothionate (TBPS) of $\mathrm{GABA}_{\mathrm{A}}$-receptor mediated $\mathrm{Cl}^{-}$-current responses in rat striatal neurones. Br. J. Pharmacol. 2000; 129:402-408

[138] Grasshoff C, Antkowiak B. Effects of isoflurane and enflurane on GABA $A_{A}$ and glycine receptors contribute equally to depressant actions on spinal ventral horn neurones in rats. $\mathrm{Br} \mathrm{J}$ Anaesth 2006; 97(5): 687-94.

[139] Li GD, Chiara DC, Cohen JB, Olsen RW. Numerous classes of general anesthetics inhibit etomidate binding to $\gamma$-aminobutyric acid type $\mathrm{A}\left(\mathrm{GABA}_{\mathrm{A}}\right)$ receptors. $\mathrm{J}$ Biol Chem 2010; 285(12): 8615-20.

[140] Jones MV, Harrison NL, Pritchett DB, Hales TG. Modulation of the GABAA receptor by propofol is independent of the $\gamma$ subunit. J Pharmacol Exp Ther 1995; 274(2): 962-8. 
[141] Belelli D, Lambert JJ, Peters JA, Wafford K, Whiting PJ. The interaction of the general anesthetic etomidate with the $\gamma$-aminobutyric acid type A receptor is influenced by a single amino acid. Proc Natl Acad Sci USA 1997; 94: 11031-6.

[142] Jurd R, Arras M, Lambert S, et al. General anesthetic actions in vivo strongly attenuated by a point mutation in the GABA(A) receptor $\beta 3$ subunit. FASEB J 2003; 17(2): 250-2.

[143] Krasowski MD, O'Shea SM, Rick CE, et al. $\alpha$ subunit isoform influences GABA(A) receptor modulation by propofol. Neuropharmacology 1997; 36(7): 941-9.

[144] Lam DW, Reynolds JN. Modulatory and direct effects of propofol on recombinant $\mathrm{GABA}_{\mathrm{A}}$ receptors expressed in xenopus oocytes: influence of $\alpha$ - and $\gamma 2$-subunits. Brain Res 1998; 784: 179-87.

[145] Feng HJ, Macdonald RL. Multiple actions of propofol on $\alpha \beta \gamma$ and $\alpha \beta \delta \mathrm{GABA}_{\mathrm{A}}$ receptors. Mol Pharmacol 2004; 66: 1517-24.

[146] O'Shea SM, Williams CA, Jenkins A. Inverse effects on gating and modulation caused by a mutation in the M2-M3 Linker of the GABA(A) receptor $\gamma$ subunit. Mol Pharmacol 2009; 76: 641-51.

[147] Moraga-Cid G, Yevenes GE, Schmalzing G, Peoples RW, Aguayo LG. A Single phenylalanine residue in the main intracellular loop of $\alpha 1 \gamma$-aminobutyric acid type $A$ and glycine receptors influences their sensitivity to propofol. Anesthesiology 2011; 115(3): 46473.

[148] Krasowski MD, Koltchine VV, Rick CE, Ye Q, Finn SE, Harrison NL. Propofol and other intravenous anesthetics have sites of action on the $\gamma$-aminobutyric acid type A receptor distinct from that for isoflurane. Mol Pharmacol 1998; 53(3): 530-8.

[149] Krasowski MD, Nishikawa K, Nikolaeva N, Lin A, Harrison NL. Methionine 286 in transmembrane domain 3 of the $\mathrm{GABA}_{\mathrm{A}}$ receptor $\beta$ subunit controls a binding cavity for propofol and other alkylphenol general anesthetics. Neuropharmacology 2001; 41: 952-64.

[150] Richardson JE, Garcia PS, O'Toole KK, Derry JM, Bell SV, Jenkins A. A conserved tyrosine in the $\beta 2$ subunit M4 segment is a determinant of $\gamma$-aminobutyric acid type A receptor sensitivity to propofol. Anesthesiology 2007; 107(3): 412-8. 
[151] Sieghart R, Jurd R, Rudolph U. Molecular determinants for the action of general anesthetics at recombinant $\alpha_{2} \beta_{3} \gamma_{2} \gamma$-aminobutyric acid ${ }_{A}$ receptors. $J$ Neurochem 2002; 80: $140-8$.

[152] Yip GM, Chen ZW, Edge CJ, et al. A propofol binding site on mammalian GABA receptors identified by photolabeling. Nat Chem Biol 2013; 9(11): 715-20.

[153] Li GD, Chiara DC, Sawyer GW, Husain SS, Olsen RW, Cohen JB. Identification of a $\mathrm{GABA}_{\mathrm{A}}$ receptor anesthetic binding site at subunit interfaces by photolabeling with an etomidate analog. J Neurosci 2006; 26(45): 11599-605.

[154] Chiara DC, Dostalova Z, Jayakar SS, Zhou X, Miller KW, Cohen JB. Mapping general anesthetic binding site(s) in human $\alpha 1 \beta 3 \gamma$-aminobutyric acid type A receptors with [ $\left.{ }^{3} \mathrm{H}\right]$ TDBzl-etomidate, a photoreactive etomidate analogue. Biochemistry 2012; 51(4): 83647.

[155] Kwan P, Brodie MJ. Phenobarbital for the treatment of epilepsy in the 21st century: a critical review. Epilepsia 2004; 45(9): 1141-9.

[156] Longone P, di Michele F, D'Agati E, Romeo E, Pasini A, Rupprecht R. Neurosteroids as neuromodulators in the treatment of anxiety disorders. Front Endocrinol (Lausanne) 2011; 2: 55 .

[157] Greenfield LJ Jr. Molecular mechanisms of antiseizure drug activity at GABA $_{A}$ receptors. Seizure 2013; 22(8): 589-600.

[158] Hevers W, Lüddens H. The Diversity of GABAA Receptors. Mol Neurobiol 1998; 18 : $35-86$.

[159] Thompson SA, Whiting PJ, Wafford KA. Barbiturate interactions at the human GABA receptor-dependence on receptor subunit composition. Br J Pharmacol 1996; 117: 521-7.

[160] Steinbach JH, Akk G. Modulation of $\mathrm{GABA}_{\mathrm{A}}$ receptor channel gating by pentobarbital. J Physiol 2001; 537: 715-33. 
[161] Dalziel JE, Cox GB, Gage PW, Birnir B. Mutant human $\alpha_{1} \beta_{1}(\mathrm{~T} 260 \mathrm{Q}) \mathrm{GABA}_{\mathrm{A}}$ receptors are directly activated but not modulated by pentobarbital. Eur J Pharmacol 1999; 385: 283-6.

[162] Smith AJ, Alder L, Silk J, et al. Effect of $\alpha$ subunit on allosteric modulation of ion channel function in stably expressed human recombinant $\gamma$-aminobutyric $\operatorname{acid}_{\mathrm{A}}$ receptors determined using ${ }^{36} \mathrm{Cl}$ ion flux. Mol Pharmacol 2001; 59: 1108-18.

[163] Greenfield LJ Jr., Zaman SH, Sutherland ML, et al. Mutation of the GABA $A_{A}$ receptor M1 transmembrane proline increases GABA affinity and reduces barbiturate enhancement. Neuropharmacology 2002; 42: 502-21.

[164] Carlson BX, Engblom AC, Kristiansen U, Schousboe A, Olsen RW. A single glycine residue at the entrance to the first membrane-spanning domain of the $\gamma$-aminobutyric acid type A receptor $\beta 2$ subunit affects allosteric sensitivity to GABA and anesthetics. Mol Pharmacol 2000; 57: 474-84.

[165] Chiara DC, Jayakar SS, Zhou X, et al. Specificity of intersubunit general anestheticbinding sites in the transmembrane domain of the human $\alpha 1 \beta 3 \gamma 2 \gamma$-aminobutyric acid type A $\left(\mathrm{GABA}_{\mathrm{A}}\right)$ receptor. J Biol Chem 2013; 288(27): 19343-57.

[166] Leśkiewicz M, Budziszewska B, Basta-Kaim A, Zajac A, Kaciński M, Lasoń W. Effects of neurosteroids on neuronal survival: molecular basis and clinical perspectives. Acta Neurobiol Exp (Wars) 2006; 66(4): 359-67.

[167] Lambert JJ, Cooper MA, Simmons RD, Weir CJ, Belelli D. Neurosteroids: endogenous allosteric modulators of GABA(A) receptors. Psychoneuroendocrinology 2009; 34: S48-S58.

[168] Lambert JJ, Belelli D, Harney SC, Peters JA, Frenguelli BG. Modulation of native and recombinant $\mathrm{GABA}(\mathrm{A})$ receptors by endogenous and synthetic neuroactive steroids. Brain Res Brain Res Rev 2001; 37(1-3): 68-80.

[169] Belelli D, Casula A, Ling A, Lambert JJ. The influence of subunit composition on the interaction of neurosteroids with $\mathrm{GABA}_{\mathrm{A}}$ receptors. Neuropharmacology 2002; 43: 651-61. 
[170] Mennerick S, He Y, Jiang X, et al. Selective antagonism of 5 $\alpha$-reduced neurosteroid effects at $\mathrm{GABA}_{\mathrm{A}}$ receptor. Mol Pharmacol 2004; 65: 1191-7.

[171] Herd MB, Belelli D, Lambert JJ. Neurosteroid modulation of synaptic and extrasynaptic GABA(A) receptors. Pharmacol Ther 2007; 116(1): 20-34.

[172] Rupprecht R, Holsboer F. Neuroactive steroids in neuropsychopharmacology. Int Rev Neurobiol 2001; 46: 461-77.

[173] Xilouri M, Papazafiri P. Anti-apoptotic effects of allopregnanolone on P19 neurons. Eur J Neurosci 2006; 23: 43-54.

[174] Borowicz KK, Piskorska B, Banach M, Czuczwar SJ. Neuroprotective actions of neurosteroids. Front Endocrinol (Lausanne) 2011; 2: 50.

[175] Wei J, Xiao GM. The neuroprotective effects of progesterone on traumatic brain injury: current status and future prospects. Acta Pharmacol Sin 2013; 34(12): 1485-90.

[176] Shu HJ, Eisenman LN, Jinadasa D, Covey DF, Zorumski CF, Mennerick S. Slow actions of neuroactive steroids at GABAA receptors. J Neurosci 2004; 24(30): 6667-75.

[177] Hosie AM, Wilkins ME, da Silva HM, Smart TG. Endogenous neurosteroids regulate $\mathrm{GABA}_{\mathrm{A}}$ receptors through two discrete transmembrane sites. Nature 2006; 444(7118): 486-9.

[178] Akk G, Li P, Bracamontes J, Reichert DE, Covey DF, Steinbach JH. Mutations of the GABA-A receptor $\alpha 1$ subunit M1 domain reveal unexpected complexity for modulation by neuroactive steroids. Mol Pharmacol 2008; 74: 614-27.

[179] Bracamontes J, McCollum M, Esch C, et al. Occupation of either site for the neurosteroid allopregnanolone potentiates the opening of the $\mathrm{GABA}_{\mathrm{A}}$ receptor induced from either transmitter binding site. Mol Pharmacol 2011; 80(1): 79-86.

[180] Chisari M, Eisenman LN, Covey DF, Mennerick S, Zorumski CF. The sticky issue of neurosteroids and GABA(A) receptors. Trends Neurosci 2010; 33(7): 299-306.

[181] Wohlfarth KM, Bianchi MT, Macdonald RL. Enhanced neurosteroid potentiation of ternary $\mathrm{GABA}_{\mathrm{A}}$ receptors containing the $\delta$ subunit. J Neurosci 2002; 22: 1541-9. 
[182] Puia G, Mienville J-M, Matsumoto K, et al. On the putative physiological role of allopregnanolone on $\mathrm{GABA}_{\mathrm{A}}$ receptor function. Neuropharmacology 2003; 44: 49-55.

[183] Akk G, Covey DF, Evers AS, Mennerick S, Zorumski CF, Steinbach JH. Kinetic and structural determinants for GABA-A receptor potentiation by neuroactive steroids. Curr Neuropharmacol 2010; 8: 18-25.

[184] Im WB, Pregenzer JF, Thomsen DR. Effects of GABA and various allosteric ligands on

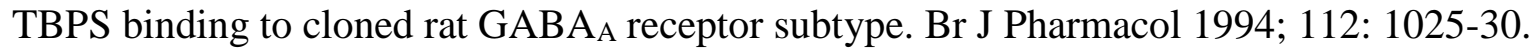

[185] Ahboucha S, Desjardins P, Chatauret N, Pomier-Layrargues G, Butterworth RF. Normal coupling of brain benzodiazepine and neurosteroid modulatory sites on the GABA-A receptor complex in human hepatic encephalopathy. Neurochem Int 2003; 43(6): 551-6.

[186] Ahboucha S, Coyne L, Hirakawa R, Butterworth RF, Halliwell RF. An interaction between benzodiazepines and neuroactive steroids at $\mathrm{GABA}_{\mathrm{A}}$ receptors in cultured hippocampal neurons. Neurochem Int 2006; 48: 703-7.

[187] Darbandi-Tonkabon R, Hastings WR, Zeng CM, et al. Photoaffinity labeling with a neuroactive steroid analogue. 6-azi-pregnanolone labels voltage-dependent anion channel-1 in rat brain. J Biol Chem 2003; 278(15): 13196-206.

[188] Park-Chung M, Malayev A, Purdy RH, Gibbs TT, Farb DH. Sulfated and unsulfated steroids modulate $\gamma$-aminobutyric acid $_{\mathrm{A}}$ receptor function through distinct sites. Brain Res 1999; 830: 72-87.

[189] Brown N, Kerby J, Bonnert TP, Whiting PJ, Wafford KA. Pharmacological characterization of a novel cell line expressing human $\alpha_{4} \beta_{3} \delta$ receptors. Br J Pharmacol 2002, 136: $965-74$.

[190] Stell BM, Brickley SG, Tang CY, Farrant M, Mody I. Neuroactive steroids reduce neuronal excitability by selectively enhancing tonic inhibition mediated by $\delta$ subunitcontaining GABAA receptors. Proc Natl Acad Sci USA 2003; 100: 14439-44. 
[191] Whissell PD, Eng D, Lecker I, Martin LJ, Wang DS, Orser BA. Acutely increasing $\delta$ GABA(A) receptor activity impairs memory and inhibits synaptic plasticity in the hippocampus. Front Neural Circuits 2013; 7: 146.

[192] Zheleznova N, Sedelnikova A, Weiss DS. $\alpha 1 \beta 2 \delta$, a silent GABAA receptor: recruitment by tracazolate and neurosteroids. Br J Pharmacol 2008; 153(5): 1062-71.

[193] Harney SC, Frenguelli BG, Lambert JJ. Phosphorylation influences neurosteroid modulation of synaptic $\mathrm{GABA}_{\mathrm{A}}$ receptors in rat $\mathrm{CA} 1$ and dentate gyrus neurones. Neuropharmacology 2003; 45: 873-83.

[194] Korpi ER, Sinkkonen S. GABAA receptor subtypes as targets for neuropsychiatric drug development. Pharmacol Ther 2006; 109: 12-32.

[195] Reddy DS. Neurosteroids: endogenous role in the human brain and therapeutic potentials. Prog Brain Res 2010; 186: 113-37.

[196] Reddy DS, Rogawski MA. Ganaxolone suppression of behavioral and electrographic seizures in the mouse amygdala kindling model. Epilepsy Res 2010; 89(2-3): 254-260.

[197] Broomall E, Natale JE, Grimason M, et al. Pediatric super-refractory status epilepticus treated with allopregnanolone. Ann Neurol 2014; 76(6): 911-5.

[198] Borghese CM, Stórustovu Sí, Ebert B, et al. The $\delta$ subunit of $\gamma$-aminobutyric acid type A receptors does not confer sensitivity to low concentrations of ethanol. J Pharmacol Exp Ther 2006; 316(3): 1360-8.

[199] Wallner M, Hanchar HJ, Olsen RW. Ethanol enhances $\alpha_{4} \beta_{3} \delta$ and $\alpha_{6} \beta_{3} \delta \gamma$-aminobutyric acid type A receptors at low concentrations known to affect humans. Proc Natl Acad Sci USA 2003; 100: 15218-23.

[200] Baur R, Kaur KH, Sigel E. Structure of $\alpha 6 \beta 3 \gamma$ GABA(A) receptors and their lack of ethanol sensitivity. J Neurochem 2009; 111(5): 1172-81.

[201] Marutha Ravindran CR, Mehta AK, Ticku MK. Effect of chronic administration of ethanol on the regulation of the $\delta$-subunit of $\operatorname{GABA}(\mathrm{A})$ receptors in the rat brain. Brain Res 2007; 1174: 47-52. 
[202] Jin Z, Bazov I, Kononenko O, Korpi ER, Bakalkin G, Birnir B. Selective Changes of GABA(A) Channel Subunit mRNAs in the Hippocampus and Orbitofrontal Cortex but not in Prefrontal Cortex of Human Alcoholics. Front Cell Neurosci 2012; 5: 30.

[203] Lindemeyer AK, Liang J, Marty VN, et al. Ethanol-induced plasticity of $\mathrm{GABA}_{\mathrm{A}}$ receptors in the basolateral amygdala. Neurochem Res 2014; 39(6):1162-1170

[204] Oršolić N, Benković V, Lisičić D, Đikić D, Erhardt J, Horvat-Knežević A. Protective effects of propolis and related polyphenolic/flavonoid compounds against toxicity induced by irinotecan. Med Oncol 2010; 27: 1346-58.

[205] Oršolić N, Sirovina D, Gajski G, Garaj-Vrhovac V, Jazvinšćak Jembrek M, Kosalec I. Assessment of DNA damage and lipid peroxidation in diabetic mice: effects of propolis and epigallocatechin gallate (EGCG). Mutat Res 2013; 757(1): 36-44.

[206] Jazvinšćak Jembrek M, Vuković L, Puhović J, Erhardt J, Oršolić N. Neuroprotective effect of quercetin against hydrogen peroxide-induced oxidative injury in P19 neurons. J Mol Neurosci 2012; 47: 286-299.

[207] Hui KM, Wang XH, Xue H. Interaction of flavones from the roots of Scutellaria baicalensis with the benzodiazepine site. Planta Med 2000; 66(1): 91-3.

[208] Hanrahan JR, Chebib M, Johnston GA. Flavonoid modulation of GABA(A) receptors. Br J Pharmacol 2011; 163(2): 234-45.

[209] Wolfman C, Viola H, Marder M, et al. Anxioselective properties of 6,3'-dinitroflavone, a high-affinity benzodiazepine receptor ligand. Eur J Pharmacol 1996; 318(1): 23-30.

[210] Hall BJ, Karim N, Chebib M, Johnston GA, Hanrahan JR. Modulation of ionotropic GABA receptors by 6-methoxyflavanone and 6-methoxyflavone. Neurochem Res 2014; 39(6):1068-78.

[211] Medina JH, Viola H, Wolfman C, et al. Neuroactive flavonoids: new ligands for the benzodiazepine receptors. Phytomedicine 1998; 5(3): 235-43. 
[212] Salgueiro JB, Ardenghi P, Dias M, Ferreira MB, Izquierdo I, Medina JH. Anxiolytic natural and synthetic flavonoid ligands of the central benzodiazepine receptor have no effect on memory tasks in rats. Pharmacol Biochem Behav 1997; 58(4): 887-91.

[213] Kavvadias D, Sand P, Youdim KA, et al. The flavone hispidulin, a benzodiazepine receptor ligand with positive allosteric properties, traverses the blood-brain barrier and exhibits anticonvulsive effects. Br J Pharmacol 2004; 142(5): 811-20.

[214] Wang F, Xu Z, Yuen CT, et al. 6,2'-Dihydroxyflavone, a subtype-selective partial inverse agonist of $\mathrm{GABA}_{\mathrm{A}}$ receptor benzodiazepine site. Neuropharmacology 2007; 53(4): 574-82.

[215] Hanrahan JR, Chebib M, Johnston GA. Interactions of flavonoids with ionotropic GABA receptors. Adv Pharmacol 2015; 72: 189-200.

[216] Kim HJ, Lee BH, Choi SH, et al.Differential effects of quercetin glycosides on GABAC receptor channel activity. Arch Pharm Res 2015; 108-14.

[217] Lau BK, Karim S, Goodchild AK, Vaughan CW, Drew GM. Menthol enhances phasic and tonic $\mathrm{GABA}_{\mathrm{A}}$ receptor-mediated currents in midbrain periaqueductal grey neurons. $\mathrm{Br} \mathrm{J}$ Pharmacol 2014; (1): 2803-13.

[218] Chebib M, Johnston GAR. The 'ABC' of GABA receptors: a brief review. Clin Exp Pharmacol Physiol 1999; 26: 937-40.

[219] Johnston GAR. Medicinal chemistry and molecular pharmacology of GABAC receptors. Curr Top Med Chem 2000; 2: 903-13.

[220] Johnston GAR. GABA(A) receptor channel pharmacology. Curr Pharm Des 2005; 11(15): 1867-85.

[221] Zhang D, Pan Z-H, Awobuluyi M, Lipton SA. Structure and function of GABAC receptors: a comparison of native versus recombinant receptors. Trends Pharmacol Sci 2001; 22: 121-32.

[222] Ng CK, Kim HL, Gavande N, et al. Medicinal chemistry of $\rho$ GABAC receptors. Future Med Chem 2011; 3(2): 197-209. 
[223] Cunha C, Monfils MH, Ledoux JE. GABA(C) Receptors in the Lateral Amygdala: A Possible Novel Target for the Treatment of Fear and Anxiety Disorders? Front Behav Neurosci 2010; 4: 6.

[224] Gavande N, Kim HL, Doddareddy MR, Johnston GA, Chebib M, Hanrahan JR. Design, synthesis, and pharmacological evaluation of fluorescent and biotinylated antagonists of $\rho 1$ GABAC receptors. ACS Med Chem Lett 2013; 4(4): 402-7.

[225] Johnston GAR. Advantages of an antagonist: bicuculline and other GABA antagonists. Br J Pharmacol 2013; 169(2): 328-36.

[226] Morris KDW, Moorefield CN, Amin J. Differential modulation of the $\gamma$-aminobutyric acid type C receptor by neuroactive steroids. Mol Pharmacol 1999; 56: 752-9.

[227] Johnston GAR. GABAA receptor pharmacology. Pharmacol Ther 1996; 69: 173-98.

[228] Zhang J, Xue F, Chang Y. Structural determinants for antagonist pharmacology that distinguish the rho1 $\mathrm{GABA}_{\mathrm{C}}$ receptor from $\mathrm{GABA}_{\mathrm{A}}$ receptors. Mol Pharmacol 2008; 74(4): 941-51.

[229] Enz R, Cuting GR. Identification of 70 amino acids important for $\mathrm{GABA}_{\mathrm{C}}$ receptor $\rho 1$ subunit assembly. Brain Res 1999; 846: 177-85.

[230] Adamian L, Gussin HA, Tseng YY, et al. Structural model of rho1 GABA $A_{C}$ receptor based on evolutionary analysis: Testing of predicted protein-protein interactions involved in receptor assembly and function. Protein Sci 2009; 18(11): 2371-83.

[231] Estrada-Mondragón A, Reyes-Ruiz JM, Martínez-Torres A, Miledi R. Structurefunction study of the fourth transmembrane segment of the GABAp1 receptor. Proc Natl Acad Sci USA 2010; 107(41): 17780-4.

[232] Torres VI, Weiss DS. Identification of a tyrosine in the agonist binding site of the homomeric $\rho 1 \quad \gamma$-aminobutyric acid (GABA) receptor that, when mutated, produces spontaneous opening. J Biol Chem 2002; 277: 43741-8.

[233] Amin J. A single hydrophobic residue confers barbiturate sensitivity to $\gamma$-aminobutyric acid type C receptor. Mol Pharmacol 1999; 55: 411-23. 
[234] Alakuijala A, TalviOja K, Pasternack A, Pasternack M. Functional characterization of rat $\rho 2$ subunits expressed in HEK 293 cells. Eur J Neurosci 2005; 21(3): 692-700.

[235] Goutman JD, Calvo DJ. Studies on the mechanisms of action of picrotoxin, quercetin and pregnanolone at the GABA $\rho 1$ receptor. Br J Pharmacol 2004; 41(4): 717-27.

[236] Wang TL, Hackam AS, Guggino WB, Cutting GR. A single amino acid in $\gamma$ aminobutyric acid $\rho 1$ receptors affects competitive and noncompetitive components of picrotoxin inhibition. Proc Natl Acad Sci USA 1995; 92(25): 11751-5.

[237] Bettler B, Kaupmann K, Mosbacher J, Gassmann M. Molecular structure and physiological functions of GABA(B) receptors. Physiol Rev 2004; 84(3): 835-67.

[238] Bowery NG, Hudson AL, Price GW. GABAA and GABAB receptor site distribution in the rat central nervous system. Neuroscience 1987; 20(2): 365-83.

[239] Armijo JA, Shushtarian M, Valdizan EM, Cuadrado A, de las Cuevas I, Adín J. Ion channels and epilepsy. Curr Pharm Des 2005; 11(15): 1975-2003.

[240] Cryan JF, Kaupmann K. Don't worry 'B' happy!: a role for GABAB receptors in anxiety and depression. Trends Pharmacol Sci 2005; 26: 36-43.

[241] Bettler B, Tiao JY-H. Molecular diversity, trafficking and subcelullar localization of GABA $A_{B}$ receptors. Pharmacol Ther 2006; 110: 533-43.

[242] Kulik A, Vida I, Luján R, Haas CA, López-Bendito G, Shigemoto R, Frotscher M.) Subcellular localization of metabotropic GABA(B) receptor subunits $\mathrm{GABA}(\mathrm{B} 1 \mathrm{a} / \mathrm{b})$ and GABA(B2) in the rat hippocampus. J Neurosci 2003; 23(35): 11026-35.

[243] Tao W, Higgs MH, Spain WJ, Ransom CB. Postsynaptic GABA extrasynaptic $\mathrm{GABA}_{\mathrm{A}}$ receptor function in dentate gyrus granule cells. J Neurosci 2013; 33(9): 3738-43.

[244] Kaupmann K, Malitschek B, Schuler V, et al. GABA(B)-receptor subtypes assemble into functional heteromeric complexes. Nature 1998; 396(6712): 683-7. 
[245] Margeta-Mitrovic M, Jan YN, Jan LY. A trafficking checkpoint controls GABA(B) receptor heterodimerization. Neuron 2000; 27(1): 97-106.

[246] Malitschek B, Schweizer C, Keir M, et al. The N-terminal domain of $\gamma$-aminobutyric Acid(B) receptors is sufficient to specify agonist and antagonist binding. Mol Pharmacol 1999; 56(2): 448-54.

[247] Kniazeff J, Galvez T, Labesse G, Pin JP. No ligand binding in the GB2 subunit of the $\mathrm{GABA}(\mathrm{B})$ receptor is required for activation and allosteric interaction between the subunits. $\mathrm{J}$ Neurosci 2002; 22(17): 7352-61.

[248] Nomura R, Suzuki Y, Kakizuka A, Jingami H. Direct detection of the interaction between recombinant soluble extracellular regions in the heterodimeric metabotropic $\gamma$ aminobutyric acid receptor. J Biol Chem 2008; 283(8): 4665-73.

[249] Pin J-P, Kniazeff J, Binet V, et al. Activation mechanism of the heterodimeric GABA receptor. Biochem Pharmacol 2004; 68: 1565-72.

[250] Steiger JL, Bandyopadhyay S, Farb DH, Russek SJ. cAMP response element-binding protein, activating transcription factor-4, and upstream stimulatory factor differentially control hippocampal GABABR1a and GABABR1b subunit gene expression through alternative promoters. J Neurosci 2004; 24(27): 6115-26.

[251] Galvez T, Duthey B, Kniazeff J, et al. Allosteric interactions between GB1 and GB2 subunits are required for optimal GABA(B) receptor function. EMBO J 2001; 20(9): 2152-9.

[252] Pin J-P, Kniazeff J, Liu J, Binet V, Goudet C, Rondard P, Prézeau L. Allosteric functioning of dimeric class C G-protein-coupled receptors. FEBS J 2005; 272: 2947-55.

[253] Monnier C, Tu H, Bourrier E, Vol C, et al. Trans-activation between 7TM domains: implication in heterodimeric $\mathrm{GABA}_{\mathrm{B}}$ receptor activation. EMBO J 2011; 30(1): 32-42.

[254] Geng Y, Bush M, Mosyak L, Wang F, Fan QR. Structural mechanism of ligand activation in human GABA(B) receptor. Nature 2013; 504(7479): 254-9.

[255] Froestl W. Novel GABA(B) receptor positive modulators: a patent survey. Expert Opin Ther Pat 2010; 20(8): 1007-17 